\title{
Seismic structure of rifting in the Okinawa Trough, an active backarc basin of the Ryukyu (Nansei-Shoto) island arc-trench system
}

\author{
Azusa Nishizawa ${ }^{1,2^{*}} \mathbb{0}$, Kentaro Kaneda ${ }^{1}$, Mitsuhiro Oikawa ${ }^{1}$, Daishi Horiuchi ${ }^{1}$, Yukari Fujioka' ${ }^{1}$ and Chiaki Okada ${ }^{1}$
}

\begin{abstract}
The Okinawa Trough, to the southwest of Kyusyu, Japan, is an active backarc basin of the Ryukyu (Nansei-Shoto) island arc-trench system caused by the Philippine Sea plate subduction. Unlike other backarc basins around Japan, the Okinawa Trough, $1000 \mathrm{~km}$ in length, is unique because the crustal thinning due to backarc rifting is currently in progress in the entire trough. We conducted extensive seismic reflection and refraction surveys to detect detailed variation in seismic structures associated with the rifting tectonics. Seventeen seismic lines were shot, including ten across-trough and seven along-trough lines in the Okinawa Trough. Moho depths estimated mainly from PmP travel times indicate that the crust beneath the trough is thinner than that below the East China Sea shelf and the Ryukyu Island Arc. The shallowest Moho of the across-trough lines was not necessarily detected at the center of the trough, defined as the deepest water depth, but was located beneath the western margin of the northern and middle Okinawa Trough. An M7.1 earthquake occurred in the area on November 14, 2015, and intense aftershock activity was observed along the western margin of the trough. These earthquakes with extension axes of northwest-southeast direction demonstrated that the area is undergoing tectonic rifting. The Moho depth is over $25 \mathrm{~km}$ in the northern region of the Okinawa Trough and decreases down to $\sim 13 \mathrm{~km}$ as it goes to the south, and the thinnest crust of $\sim 7 \mathrm{~km}$ occurs beneath the Yaeyama Rift in the southern Okinawa Trough. Despite the crustal thinning by the backarc rifting, the P wave velocity models across the Okinawa Trough show that the continental/island arc crust composed of an upper, middle, and lower crusts is continuous between the East China Sea shelf and the Ryukyu Arc. The multichannel seismic profiles along and across the rifts in the southern Okinawa Trough show more volcanic intrusions in the southern side than in the north, which may be related to the position of the volcanic front, which is undetermined in this region.
\end{abstract}

Keywords: Okinawa Trough, Seismic structure, Backarc rifting, Crustal thinning

\section{Introduction}

A series of subduction trenches lines up on the Pacific side of the Japanese archipelago, and subductions of the Pacific plate and the Philippine Sea plate through the trenches form trench-arc-backarc systems (Fig. 1). Among them, the Okinawa Trough (OT), a backarc basin in the Ryukyu (Nansei-Shoto) arc-trench system, which

\footnotetext{
*Correspondence: azusa@mail1.accsnet.ne.jp; azusa@bosai.go.jp ${ }^{1}$ Hydrographic and Oceanographic Department, Japan Coast Guard, 3-1-1 Kasumigaseki, Chiyoda-ku, Tokyo 100-8932, Japan Full list of author information is available at the end of the article
}

is located southwest of Kyushu, is unique owing to its extensive active rifting.

The OT is around $1000 \mathrm{~km}$ long, and the water depth generally increases along the trough from $\sim 600 \mathrm{~m}$ in the north to $\sim 2300 \mathrm{~m}$ in the south (Fig. 1). The OT is divided into three regions by the westward extensions of the two large bathymetric depressions across the Ryukyu Arc: the Tokara Valley in the north and the Kerama Gap in the south. The seafloor feature in the northern OT is characterized by a gentle slope at the western margin of the trough, a flat seabed in the western half of the trough, and a rugged topography in the eastern half. Numerous knolls, smaller elevations with a rounded profile, are 

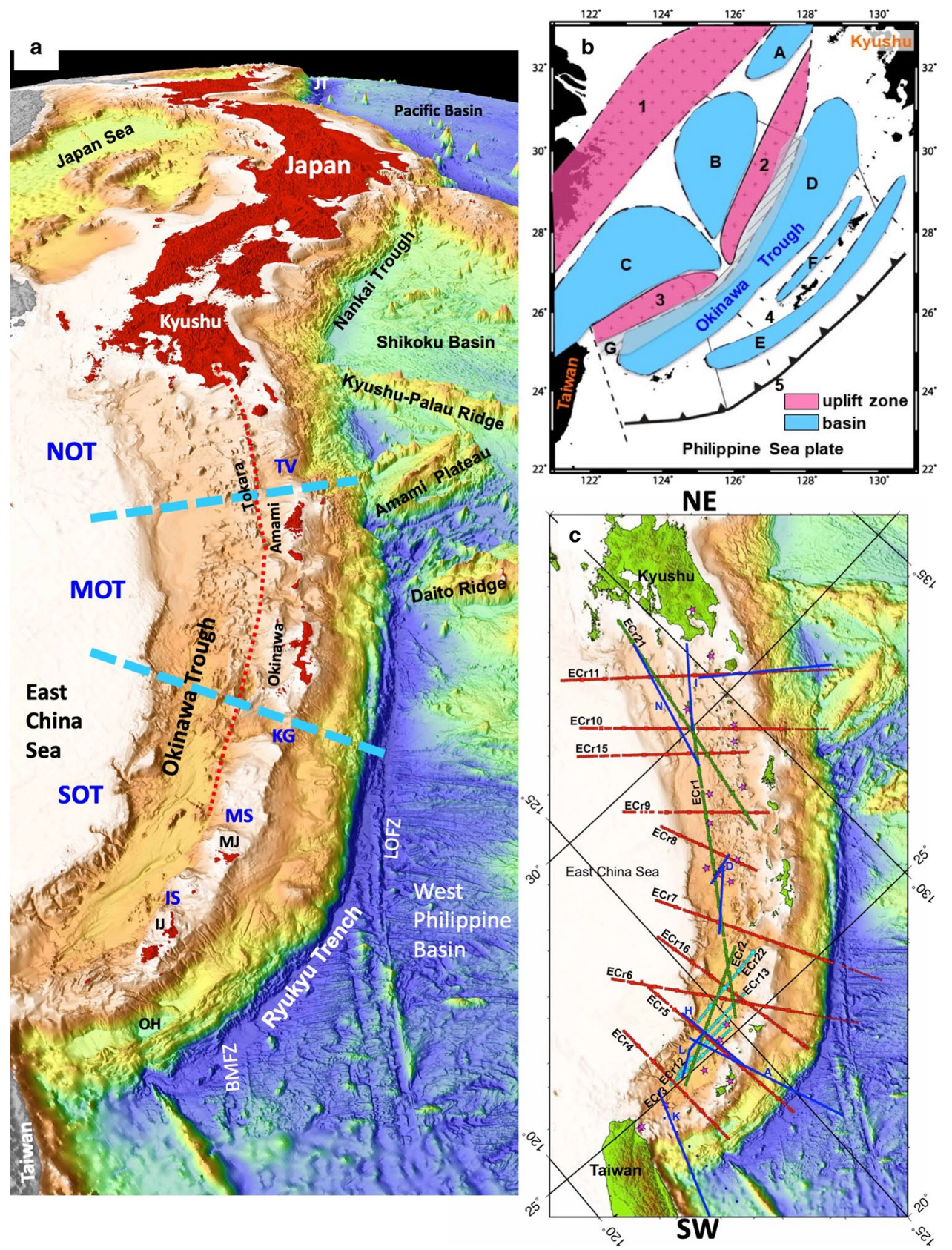

Fig. 1 a Tectonic map in and around the Okinawa Trough (OT). Sky-blue dashed lines indicate westward extension of the Tokara Valley and Kerama Gap. NOT northern Okinawa Trough, MOT middle Okinawa Trough, SOT southern Okinawa Trough, TVTokara Valley, KG Kerama Gap, MS Miyako Saddle, IS Ishigaki Saddle, MJ Miyako-jima, IJ Ishigaki-jima, LOFZ Luzon-Okinawa fracture zone, BMFZ Botan-Miyako fracture zone, OH OkiHateruma Basin. Red dotted line shows the volcanic front. b Scheme of the tectonic provinces in the East China Sea summarized by Inoue (2007). 1, Fukien-Reinan Massif; 2, Goto Uplift Zone; 3, Senkaku Uplift Zone; 4, Ryukyu Arc; 5, Ryukyu (Nansei-Shoto) Trench; A, Goto Basin; B, Tungai Basin; C, Senkaku Basin; D, Okinawa Trough; E, Ryukyu forearc basin; F, Amami Basin (Kizaki, 1985); A + B + C, East China Sea Basin (Taiwan Basin), G, Basin under Tungai Slope (Kimura 1990). c Location of the seismic lines. Red, green, and sky-blue lines are the across-trough, along-trough, and along-rift/ rift-parallel survey lines, respectively. Blue lines indicate positions of previous surveys. Iwasaki et al. (1990), Nakahigashi et al. (2004), Nagumo et al. (1986), Hirata et al. (1991), Lee et al. (1980), Arai et al. (2017), Klingehoefer et al. (2009). Violet asterisks show hydrothermal vents (http://vents-data. interridge.org/ventfields?order=name_3\&sort=asc;) 


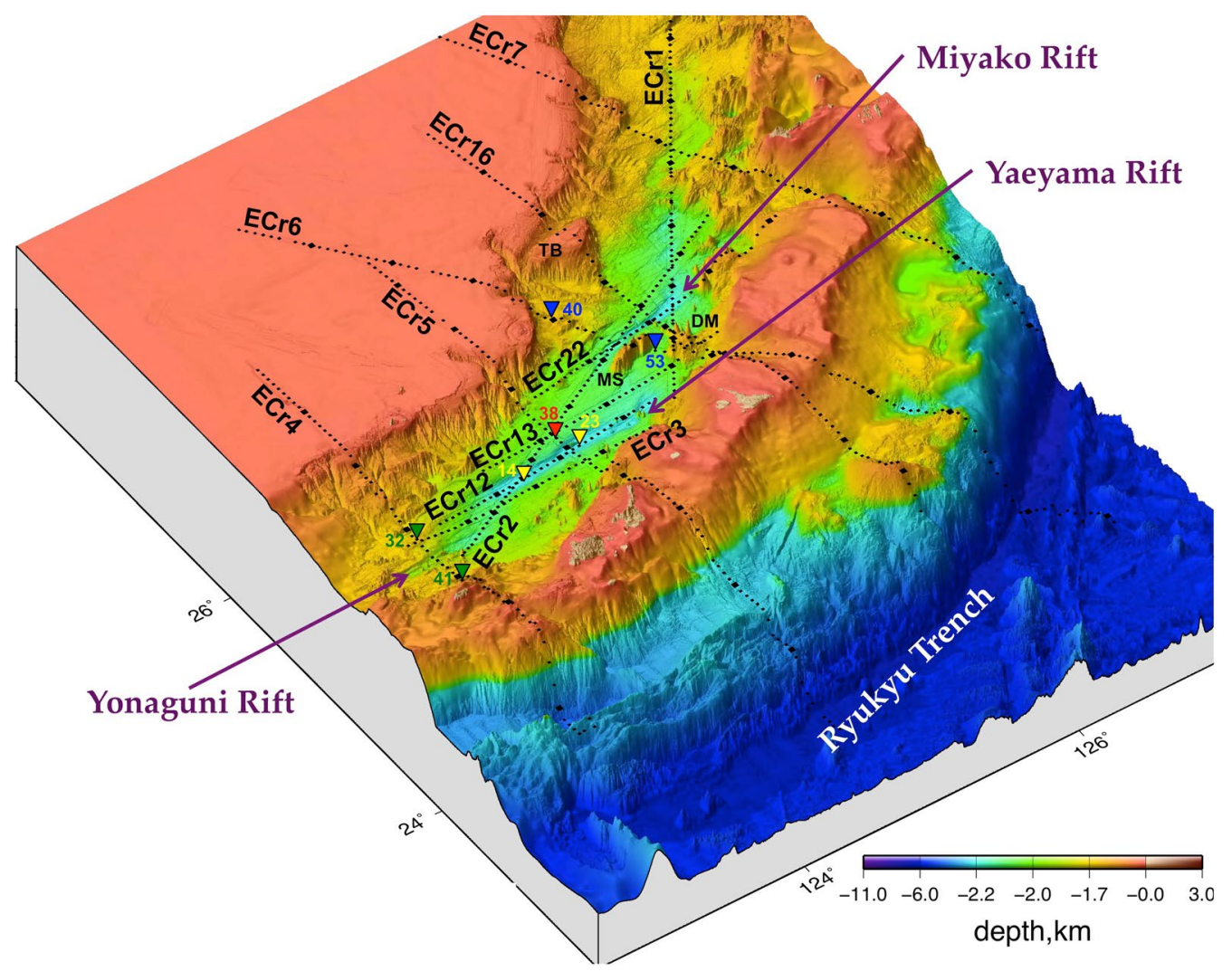

Fig. 2 Three-dimensional view of the fine bathymetry in the southern OT and the position of the seismic lines. The OBSs were deployed at each square. TB Taisho Bank, DM Daiichi-Miyako Knoll, MS Miyako Seamount

found in the eastern half of the middle OT. Along the center of the southern OT, there are several conspicuous en echelon graben structures (i.e., Miyako Rift, Yaeyama Rift, and Yonaguni Rift as shown in Fig. 2), which are elongate depressions formed by the backarc rifting. The slope at the northern margin of the southern OT shows a steeper gradient than that in the northern OT and is cut by submarine channels of varying size. Over ten hydrothermal vents have been found through the OT, and some of them have been investigated in great detail (e.g., Beaulieu 2015; Ishibashi et al. 2015; Minami and Ohara 2017). However, a volcanic front is recognizable only to the west of the Ryukyu Arc in the northern and middle OT, but not in the southern OT.

Tectonic evolution models for the OT have been discussed in many previous studies (e.g., Letouzey and Kimura 1986; Furukawa et al. 1991; Miki 1995; Park et al. 1998; Sibuet et al. 1998). For example, Sibuet et al. (1995) revealed that crustal thinning is different between the northern and southern OT based on seismic refraction and gravity data. Recently, Gungor et al. (2012) compiled multichannel seismic reflection (MCS) profiles at the northern OT and pointed out that diffuse rifting/ extension in the northern OT, in contrast to focused rifting/extension in the southern OT, is due to the tectonic perturbation caused by the convergence or subduction of the bathymetric high at the northern Ryukyu Arc.

Although the large and long seafloor depression of the $\mathrm{OT}$ is currently in progress due to the backarc rifting, there are several inactive depressions with associated ridges (elongated narrow elevations) parallel to the mainland Chinese shoreline beneath the thick sediments in the East China Sea (ECS) shelf (Fig. 1b). These inactive depressions are considered as failed rift basins. The formation age of these rift basins becomes progressively younger from NW to SE, and the youngest rift basin is the OT (e.g., Kimura 1990; Sibuet and Hsu 1997; Sibuet et al. 2004; Lin et al. 2005). Li et al. (2009) revealed that the Xihu Depression, one of the failed rift basins located within the region "B" in Fig. 1b, exhibits a thin crust similar to a typical oceanic crust. Therefore, the active rifting in the OT might stop in the future, similar to the abandoned rift basins to the west. A precise understanding of the present situation is necessary to predict future activities of the OT.

Fundamental geological and geophysical data have been collected in and around the OT by the Japan Coast 


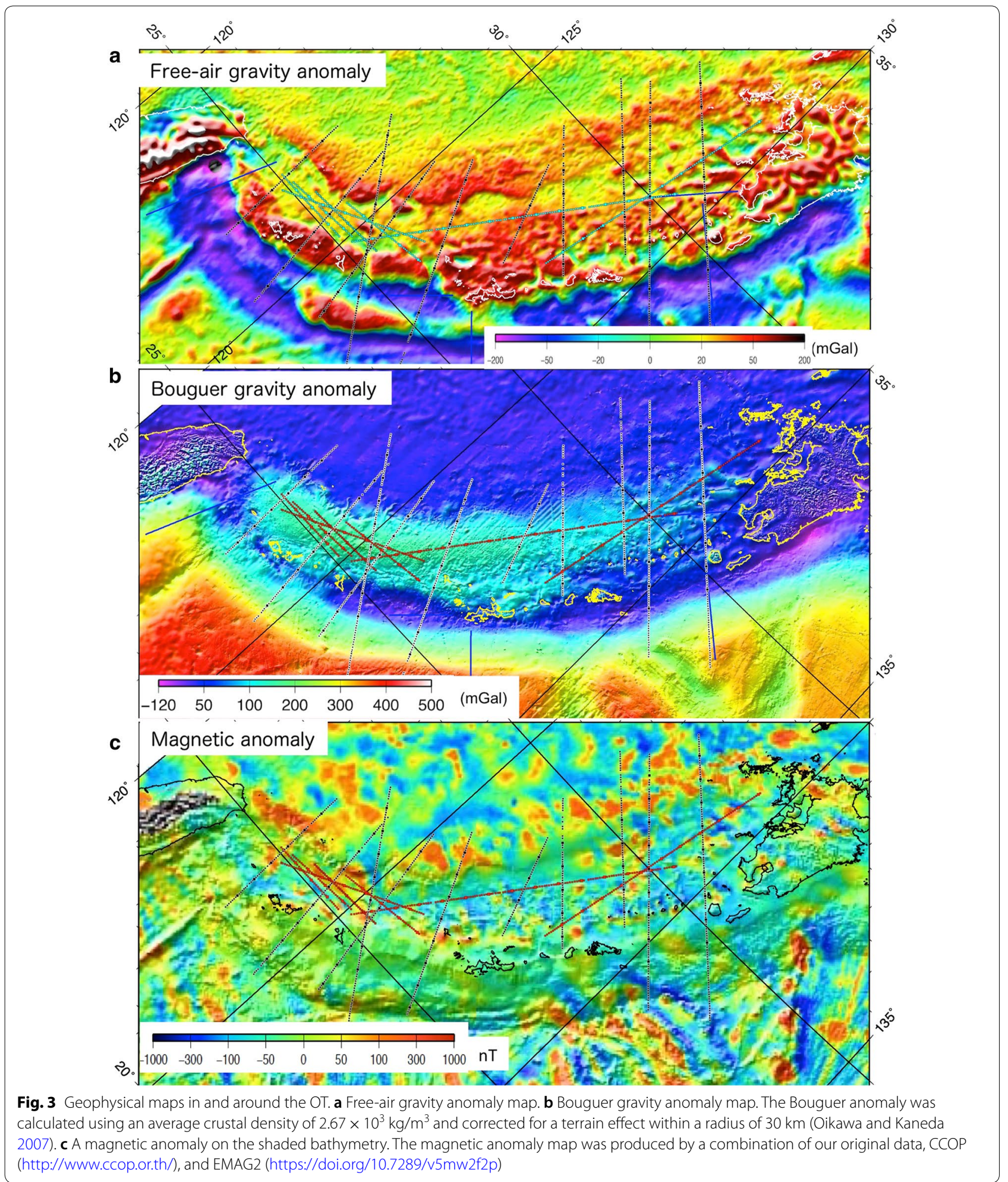

Guard under the Continental Shelf Survey Project since 1983 (e.g., Katsura et al. 1986; Oshima et al. 1988). Figure 3 summarizes geophysical data compiled since then.
The free-air gravity anomaly map generally shows a slightly positive anomaly in the OT, and its variation corresponds to the seafloor topography. However, despite 
the flat seafloor of the ECS shelf, there are distinct positive gravity anomalies along the eastern margin of the shelf, roughly parallel to the strike of the OT, which corresponds to the Goto-Senkaku Uplift Zone (TaiwanSinzi Ridge) in Fig. 1b.

The Bouguer gravity anomaly map (Fig. $3 \mathrm{~b}$ ) shows a southwestward decrease along the OT. Based on the Bouguer gravity anomaly data, the crustal thickness of the OT decreases from the northeast to southwest (Fig. 3b). Different from the free-air gravity anomaly map, there are no distinct anomalies along the eastern margin of the ECS shelf.

A magnetic anomaly map is shown in Fig. 3c. There are positive and negative anomalies of -300 to $500 \mathrm{nT}$ along the eastern margin of the ECS shelf, reflecting spatial variations in magnetic basement depths (Oshima et al. 1988). The distribution of the magnetic anomalies in the OT shows dipole anomalies related to small seamounts, knolls, and volcanic intrusions. The short linear magnetic anomalies observed in the southern OT reveal a rifted magnetized basement of the continental crust, and there are no distinct magnetic lineations indicating seafloor spreading in the OT (Oshida et al. 1992).

Information on seismic activities and structures including the deeper crust and uppermost mantle is necessary to understand regional tectonics of the OT. Large shallow earthquakes with depths $<30 \mathrm{~km}$ in the OT were not known until quite recently, except for the 1938 Miyakojima-Hokusei-oki Earthquake (M7.2) north of Miyakojima Island. However, an M7.1 earthquake occurred in 2015 at the western margin of the northern OT, where no large earthquakes have been observed before the event. From viewpoints of hazard assessment and disaster mitigation, it is crucial to investigate seismic structure in the source area of the 2015 M7.1 earthquake. Moreover, seismic velocity models are capable of providing fundamental structural constraints which contribute to constructing an evolutionary model of the OT.

Former seismic surveys have shown rough alongtrough variation in the crust of the OT. Two-ship seismic refraction experiments in the 1960-1970s have provided simple velocity distribution models in and around the OT (e.g., Murauchi et al. 1968; Ludwig et al. 1973; Lee et al. 1980). Since the 1980s, refraction experiments using ocean bottom seismographs (OBSs) as receivers have been performed at various locations in the OT, and more precise crustal models have been developed (e.g., Nagumo et al. 1986; Iwasaki et al. 1990; Nakahigashi et al. 2004; Klingelhoefer et al. 2009, 2012). Very recently, seismic reflection and refraction surveys with a much denser OBS interval and longer MCS streamer have provided more detailed seismic structures. Arai et al. (2017) accurately estimated a thin crust of $\sim 13 \mathrm{~km}$ beneath the rift in the center of the southern OT and demonstrated that the 2- to 7- $\mathrm{km}$-wide volcanic intrusion on the rift axis resulted from the passive upwelling of magma. However, such dense seismic surveys are limited in the OT and the detailed rifting structure remains unclarified yet. On the other hand, Nakamura and Umezu (2009) conducted P wave travel time inversion of natural earthquakes and showed variations in the crustal thicknesses and Pn velocities beneath the Ryukyu Arc and the OT. Compared with the seismic reflection and refraction surveys, the accuracy and resolution of the inversion result had limitations due to the insufficient number of the stations and the seismic network configuration only on the land of the Ryukyu Arc.

The Japan Coast Guard has conducted extensive seismic reflection and refraction surveys in the Nansei-Shoto region since 2008 to obtain the fundamental seismic structure using uniform high-spec seismic exploration techniques (Fig. 1). We have previously reported the seismic structure related to the subduction of the Philippine Sea plate (Okamura et al. 2017; Nishizawa et al. 2017). In the present study, we compile P wave velocity models obtained from all the 17 seismic lines and discuss regional variations in seismic structure across and along the OT. The fine shallow seismic structure of the OT, mainly based on MCS profiles, will be reported in another paper, and preliminary interpretation of $\mathrm{ECr} 1$ and $\mathrm{ECr} 10$ in the northern OT has been described by Ishibashi et al. (2015).

\section{Seismic data acquisition and processing}

We performed 17 seismic surveys: ten lines across the trough strike, three along-trough lines, and four lines along or parallel to the rift axes in the center of the southern OT (Fig. 1). The specification of our seismic survey and procedures for data processing and velocity structure modeling are the same as those described by Nishizawa et al. (2017), in which seismic structures related to the Philippine Sea plate subduction were reported using the same dataset. We used a non-tuned airgun array with a total volume of $98.4 \mathrm{~L}\left(1500 \mathrm{in}^{3} \times 4\right)$ as a controlled seismic source at an interval of $200 \mathrm{~m}(90 \mathrm{~s})$ for refraction lines and a three-gun cluster airgun, $17.1 \mathrm{~L}$ (350 in. $\left.{ }^{3} \times 3\right)$, at an interval of $50 \mathrm{~m}$ for reflection lines. OBSs deployed at a $5-\mathrm{km}$ interval and a $3000-\mathrm{m}$-long, 240-channel hydrophone streamer were used as receivers. A 480-channel streamer was used only for ECr15. We determined the location of each OBS instrument using the direct water wave arrivals (Oshida et al. 2008). Several OBSs drifted from the seismic line more than $500 \mathrm{~m}$ due to the strong Kuroshio ocean currents. 
The multichannel seismic reflection data were processed by the conventional procedure composed of resampling, common midpoint sorting at $6.25 \mathrm{~m}$ intervals except for $3.125 \mathrm{~m}$ for ECr15, bandpass filter, amplitude recovery, minimum phase conversion, predictive deconvolution, velocity analysis, multiple suppression, normal moveout correction, mute and common midpoint stack, and post-stack time migration. For time-to-depth conversion, we used the $\mathrm{P}$ wave velocity $\left(V_{\mathrm{p}}\right)$ models derived by the seismic refraction survey.

Our OBSs were equipped with three-component $4.5-\mathrm{Hz}$ geophones and a hydrophone. We mainly used vertical geophone outputs and sometimes referred hydrophone outputs for the identification of reflection phases. We obtained final $V_{\mathrm{p}}$ models using tomographic inversion (tomo2D) according to Korenaga et al. (2000) and forward modeling with two-dimensional ray tracing (Fujie et al. 2000; Kubota et al. 2009). Initial $V_{\mathrm{p}}$ models were constructed with information of sedimentary structure obtained by the MCS profile. In the two-dimensional inversion models, the horizontal grid spacing is $0.5 \mathrm{~km}$, and the vertical grid spacing gradually increases with depth according to the relation $0.05+(0.01 \times \text { depth }(\mathrm{km}))^{1 / 2} \mathrm{~km}$. We applied smoothness constraints on both velocity and depth perturbation in the models using predefined correlation lengths. We defined the correlation length function for model smoothing as follows: The horizontal correlation length for velocity nodes ranges from $1 \mathrm{~km}$ at seafloor, $3 \mathrm{~km}$ at a depth of $3 \mathrm{~km}, 5 \mathrm{~km}$ at $10 \mathrm{~km}, 20 \mathrm{~km}$ at $10 \mathrm{~km}$, $15 \mathrm{~km}$ at the model bottom, and the vertical correlation length also varies from $0.1 \mathrm{~km}$ at seafloor, $0.4 \mathrm{~km}$ at a depth of $3 \mathrm{~km}, 3 \mathrm{~km}$ at $10 \mathrm{~km}, 3 \mathrm{~km}$ at $20 \mathrm{~km}, 3 \mathrm{~km}$ at the bottom. The correlation lengths vary linearly between the depth nodes. The velocity smoothing parameter (SV) and velocity damping factor (TV) were selected to be 300 and $20 \%$, respectively, after several tests.

We examined the reliability of the inversion using conventional checkerboard resolution tests. A reference model for the test was built by adding sinusoidal anomalies with a horizontal dimension of $10 \mathrm{~km}$, a vertical dimension of $2.5 \mathrm{~km}$, and a velocity perturbation of $\pm 5 \%$ to the upper crust of our preferred final model. The vertical lengths of the cells in the middle and lower crusts are 5 and $10 \mathrm{~km}$, respectively, and the horizontal length is $20 \mathrm{~km}$. As a result, we succeeded in determining $V_{\mathrm{p}}$ models shallower than $\sim 10 \mathrm{~km}$ with misfits of less than $\sim 50 \mathrm{~ms}$ by the inversion method after 2-3 iterations. Since the recovery of the checkerboard pattern of the deeper part was insufficient, we mainly used the forward modeling to estimate deeper crust and mantle structures.
Forward modeling is useful to construct layering structural models based on reflection signals produced at a layer boundary. Especially, Moho depths are constrained by travel time fitting of wide-angle reflections from Moho. The accuracy of the depths varies depending on the locations of the seismic lines, and the potential error of the Moho depth is $1-2 \mathrm{~km}$ in the case of good travel time fitting for clear PmP signals.

The code for the forward modeling is based on the graph theory and calculates only first arrivals of refracted waves and faster-reflected waves at each layer boundary. A finite difference method, E3D (Larsen and Schultz 1995), can be used to calculate several later arrivals that cannot be estimated by the tomographic inversion and forward modeling approach. When amplitude characteristics in synthetic record sections show apparent differences from those of the observed records, we revised the $V_{\mathrm{p}}$ model by the forward modeling.

\section{Results}

We show the MCS depth-converted profile (Fig. 4), P wave velocity model (Fig. 5), and checkerboard test result with ray coverage (Fig. 6) for each line. On the whole, the crustal models in the OT show thinned continental/arc crusts of the ECS shelf and the Ryukyu Island Arc, which consists of upper $\left(V_{\mathrm{p}}<6 \mathrm{~km} / \mathrm{s}\right)$, middle $(6.0-6.5 \mathrm{~km} / \mathrm{s})$, and lower crusts $(>6.5 \mathrm{~km} / \mathrm{s})$. We describe the characteristics of each profile roughly from north to south and from west to east.

There sometimes exist discrepancies in these $V_{\mathrm{p}}$ models at intersections between the seismic lines. These differences are possibly due to three-dimensional heterogeneities and/or azimuthal anisotropies of the $V_{\mathrm{p}}$ structures. Since more detailed surveys and analyses are necessary to elucidate the causes of the inconsistencies, we only describe degrees of the differences in the $V_{\mathrm{p}}$ models in this paper.

\section{Across-trough lines}

The results for the across-trough lines ECr11, ECr10, and ECr15 in the northern OT, ECr9 and ECr8 in the middle OT, and ECr7, ECr16, ECr6, ECr5, and ECr4 in the southern OT are summarized in Figs. 4, 5, and 6.

ECr11 is the northernmost across-trough seismic line in our study. ECr11, 624-km-long line, extends from the ECS shelf at the northwestern end and crosses the OT in the middle volcanic front in the southeastern part of the line (Fig. 1). The MCS profile (Fig. 4) showed a large sedimentary basin reaching a depth of $\sim 8 \mathrm{~km}$ in the western margin of the OT. Another deep sedimentary basin exists at the western end of the profile, and there is a shallow acoustic basement between the sedimentary basins. These sedimentary basins correspond to areas 


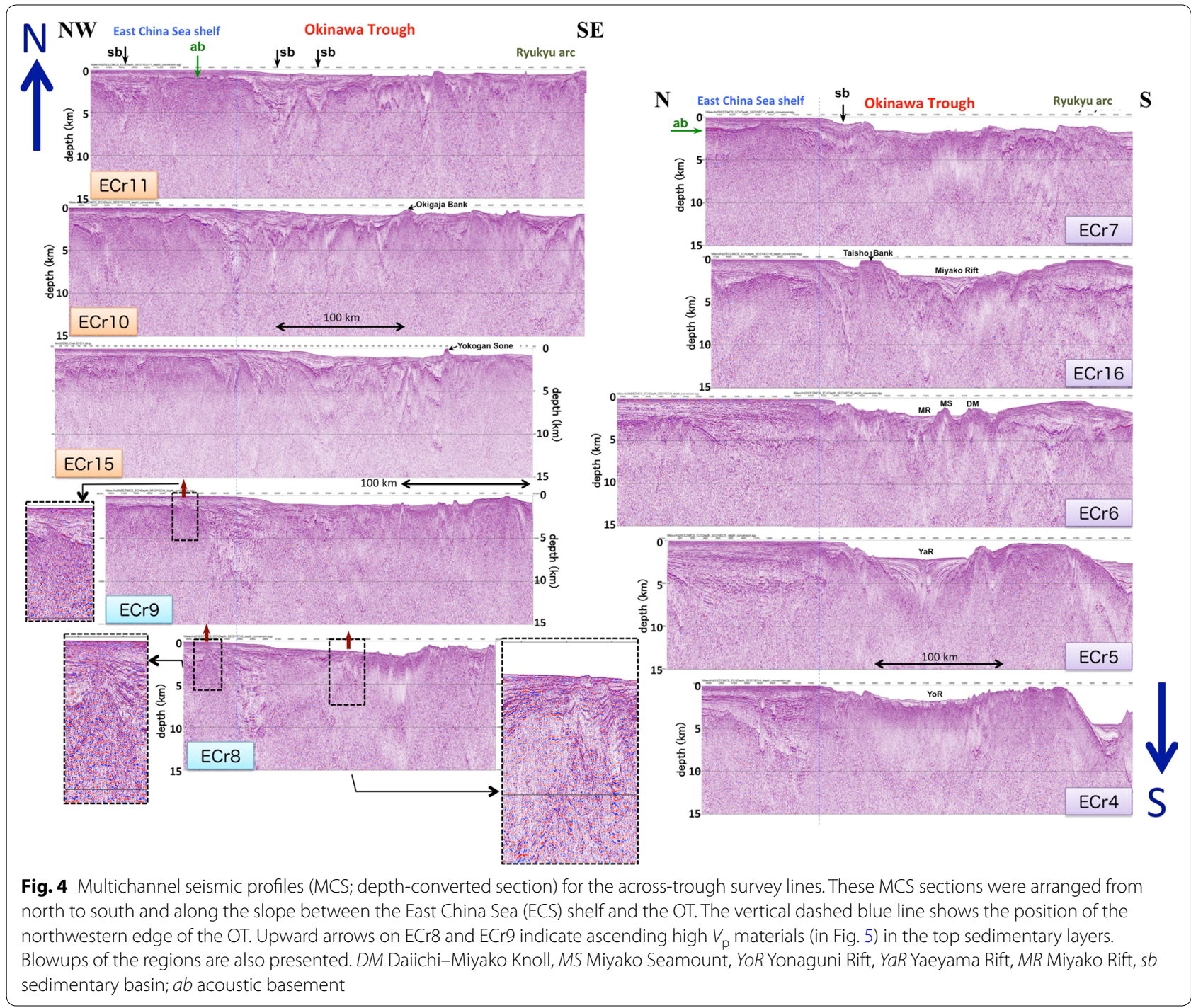

with lower $V_{\mathrm{p}}$ values than those of the surroundings in the $V_{\mathrm{p}}$ model (Fig. 5). Figure 7 shows an example of the forward modeling for OBS025 revealing that the boundary between the middle crust and lower crust beneath the ECS shelf lies at depths of $12-13 \mathrm{~km}$ and the Moho discontinuity at $\sim 33 \mathrm{~km}$. However, the velocity values in the lower crust were not precisely determined due to a lack of refracted waves, as shown in Figs. 6 and 7. The Moho depth decreases abruptly in the western margin of the OT, the transition area from the ECS shelf to the OT. Clear signals around the offset of $70 \mathrm{~km}$ were observed at $0.2 \mathrm{~s}$ before more continuous phases of PmP with calculated travel times, as shown in Fig. 7. The Moho depth decreases if we interpret them as PmP arrivals. Reflection signals from the top of the lower crust and the Moho were also observed beneath the trough (Figs. 6, 7). The
Moho depth below the trough is $26-30 \mathrm{~km}$, shallower than that below the ECS shelf. In the southeastern part of ECr11 near the volcanic front, there are several bathymetric highs correlated with shallow high $V_{\mathrm{p}}$ of $\sim 6 \mathrm{~km} / \mathrm{s}$ (Fig. 5). The estimated Pn velocity below the trough is $8 \mathrm{~km} / \mathrm{s}$ based on weak Pn signals recorded on several OBSs (e.g., Fig. 7).

ECr10 is parallel to ECr11 and $100 \mathrm{~km}$ southwest of ECr11. The MCS reflection image shows that several sedimentary basins exist in the ECS shelf and the OT along ECr10, and these structural features are similar to those along ECr11 (Fig. 4). The sedimentary basin just below the slope of the western margin of the OT is the deepest along ECr10, and an upper crust with $V_{\mathrm{p}} \leq 6 \mathrm{~km} / \mathrm{s}$ reaches $10 \mathrm{~km}$ depth (Fig. 5). Although the seafloor topography in the northwestern half of the seismic line in 

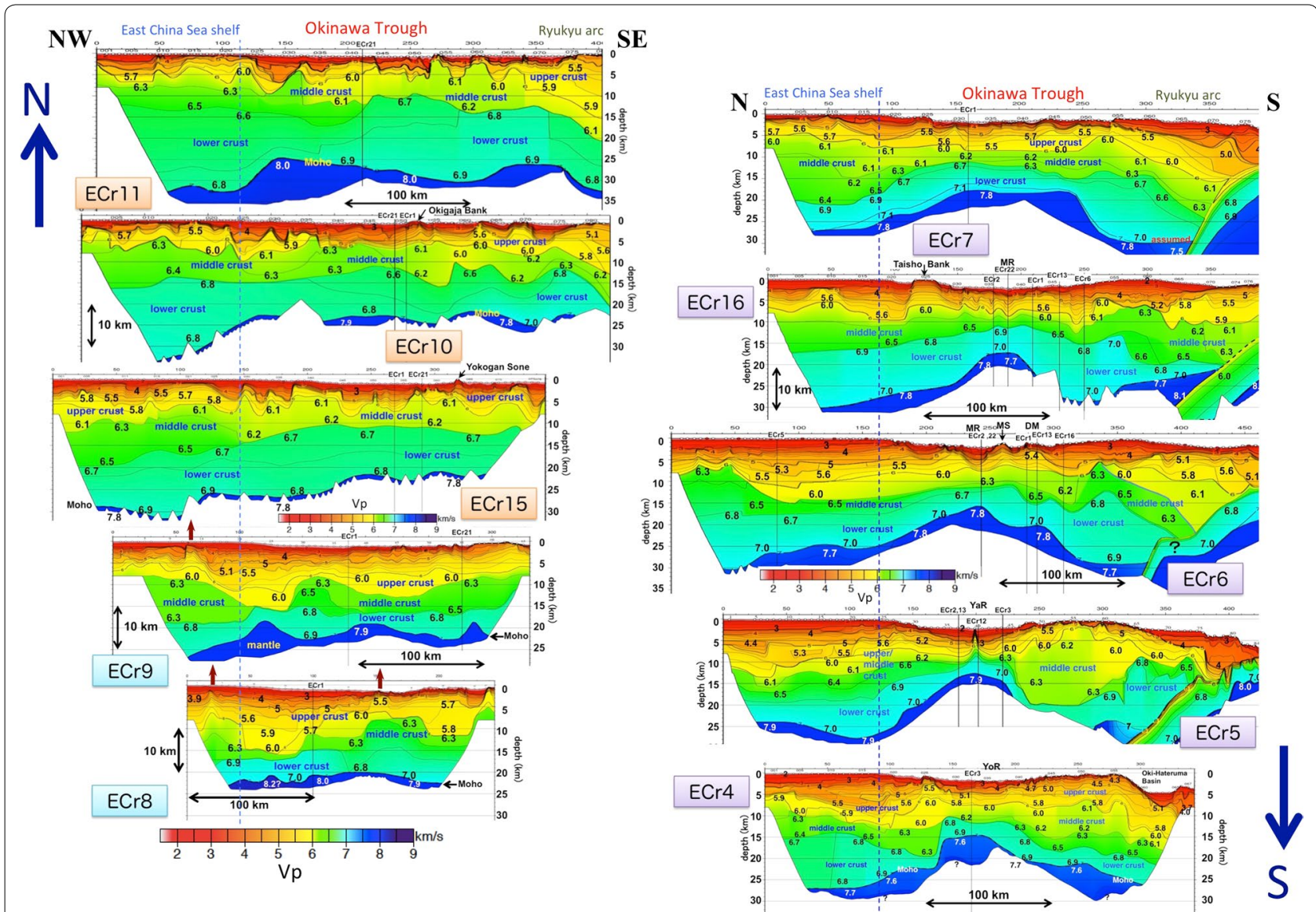

Fig. $5 \mathrm{P}$ wave velocity models for the survey lines perpendicular to the trough axes. The contour interval is $0.25 \mathrm{~km} / \mathrm{s}$. These $V_{\mathrm{p}}$ models were arranged from north to south and along the slope between the ECS shelf and the OT. The vertical dashed blue line shows the position of the northwestern edge of the OT. Upward arrows on ECr8 and ECr9 indicate ascending high $V_{p}$ materials in the top sedimentary layers. DM DaiichiMiyako Knoll, MS Miyako Seamount, YoR Yonaguni Rift, YaR Yaeyama Rift, MR Miyako Rift

the OT is flat, the sea bottom in the southeastern half is rather rugged, with several bathymetric highs. The $V_{\mathrm{p}}$ of the uppermost crust at Okigaja Bank, submerged elevation of the seafloor around the center of the OT, is higher than that of the surrounding area but is lower than that of bathymetric highs related to the volcanic front located further southeast.

Several signal groups of Moho reflections below the western margin of the OT were recorded in the same offset ranges in many OBSs. These signal groups have slightly different travel times, indicating a three-dimensional inhomogeneity in the crustal structure in this transitional area from the ECS shelf to the OT. We selected the fastest arrivals as PmP signals and used these for forward modeling. We found that the Moho depth decreases from over $30 \mathrm{~km}$ below the ECS shelf to $22-24 \mathrm{~km}$ in the OT. The estimated Pn velocity below the trough is $7.8-7.9 \mathrm{~km} / \mathrm{s}$.
ECr15 is almost parallel to ECr11 and ECr10 and is $\sim 60 \mathrm{~km}$ southwest of ECr10. Overall features of the MCS record were similar to those of ECr11 and ECr10 (Fig. 4), but the sedimentary basins were shallower below the western margin of the OT. The $V_{\mathrm{p}}$ model for ECr15 is also similar to that of ECr10 and ECr11, and the $V_{\mathrm{p}}$ of the middle crust is slightly lower below the OT and Ryukyu Arc than that beneath the ECS shelf. The seismic line is extended close to the volcanic front at its southeastern end. Although there are several heterogeneities in $V_{\mathrm{p}}$ distribution associated with the bathymetric highs, the shallow part of Yokogan Sone bank does not show higher $V_{\mathrm{p}}$. The Moho depth along ECr15 decreases from $30 \mathrm{~km}$ below the ECS shelf to $21-23 \mathrm{~km}$ below the OT. Since we could not observe signals propagating through the uppermost mantle, we assumed $P n$ velocity to be $7.8 \mathrm{~km} / \mathrm{s}$ based on the crossing seismic lines of ECr1 and ECr21.

$\mathrm{ECr} 9$ is positioned in the middle of the OT. The slope between the ECS shelf and the trough is slightly steeper 


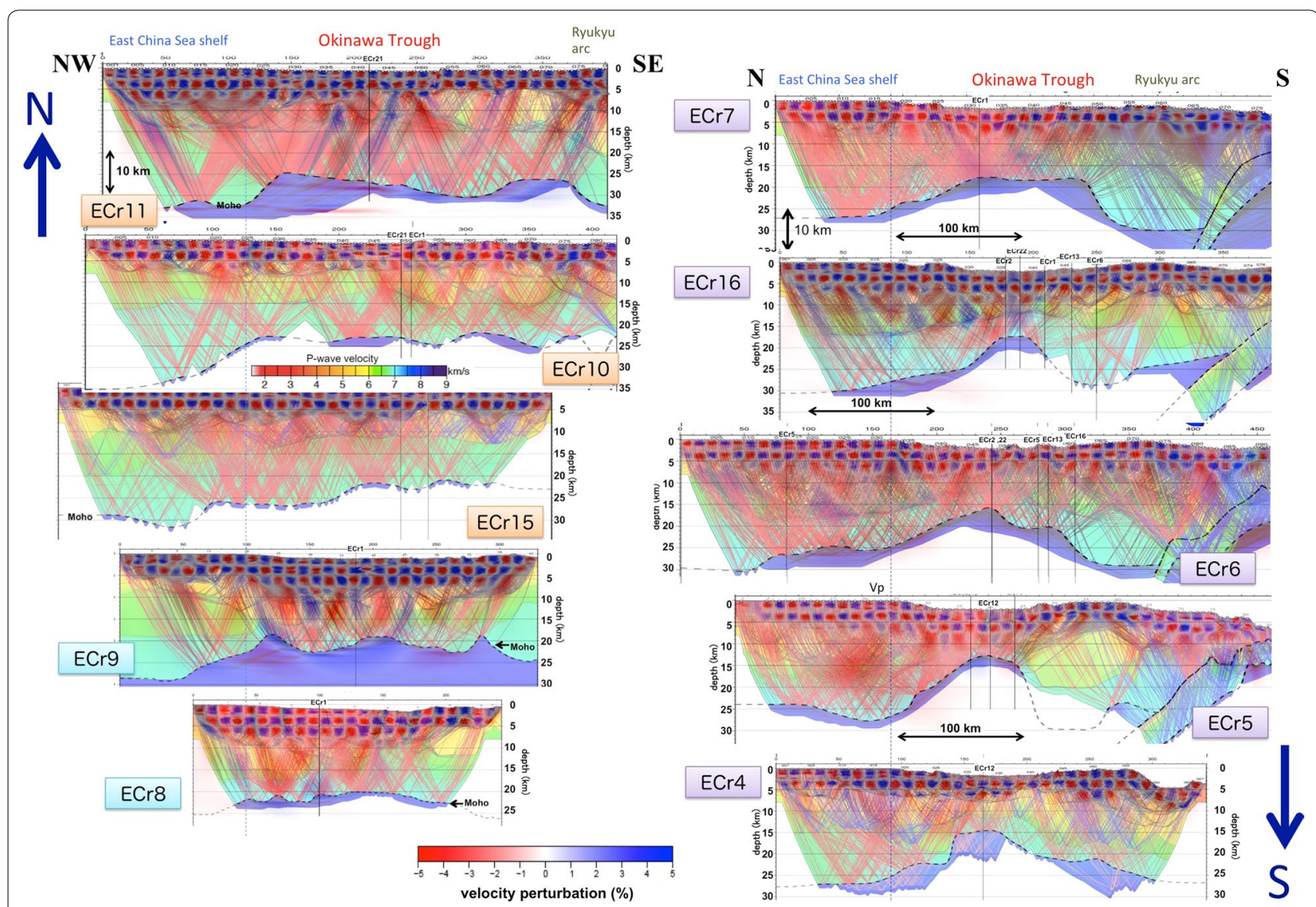

Fig. 6 Results of the checkerboard test for each P wave velocity model shown in Fig. 5. Ray coverage is also plotted from the forward modeling, including reflection waves. The ray paths correspond to manual readings on the observed record sections for each seismic line

than that of the northern seismic lines. The seafloor topography is flat in the northwestern part of the OT, but is rugged in the southeastern part, as observed in ECr10. A deep sedimentary basin also exists below the western margin of the OT in the MCS profile shown in Fig. 4, which corresponds to materials with $V_{\mathrm{p}}$ of $\sim 6 \mathrm{~km} / \mathrm{s}$ at depths over $15 \mathrm{~km}$ below the slope, and there were no materials with $V_{\mathrm{p}}$ corresponding to a typical middle crust (Fig. 5). The velocity distribution in the OT crust reveals substantial horizontal heterogeneity and is characterized by a small velocity gradient in the thick upper crust. The Moho depth of $\sim 20 \mathrm{~km}$ below the ECS shelf becomes shallow, $18 \mathrm{~km}$, and a very thin lower crust $(\sim 3 \mathrm{~km})$ is modeled for the northwestern margin of the OT. Figure 8 shows two record sections of the OBSs installed at both sides of the shallow Moho area. Synthetic seismograms for OBS016 and the calculated travel times for OBS036 reveal good consistency with the observed record sections. The number of rays propagated at the top of the mantle is small (Fig. 6), but we roughly obtained a Pn velocity of $7.9 \mathrm{~km} / \mathrm{s}$ below the OT on the basis of the $V_{\mathrm{p}}$ model for ECr1, an along-trough line.
ECr8 is located $30-120 \mathrm{~km}$ southwest of ECr9 in the middle of the OT and obliquely traverses the trough. The MCS profiles of ECr8 and ECr9 are generally similar to each other and have deeper sedimentary basins, with lots of normal faults below the slope in the northwestern margin of the OT (Fig. 4, Additional file 1: Fig. A1). An intrusion structure is observed at $\sim 20 \mathrm{~km}$ from the northwestern end of ECr8 beneath the ECS shelf, corresponding to an ascending $V_{\mathrm{p}}$ contour of $4 \mathrm{~km} / \mathrm{s}$ in the $V_{\mathrm{p}}$ model (Fig. 5). In contrast, the $V_{\mathrm{p}}$ model reveals materials with $V_{\mathrm{p}} \leq 6 \mathrm{~km} / \mathrm{s}$ prevailing down to a depth of $15 \mathrm{~km}$, with a width of over $40 \mathrm{~km}$ below the transition from the ECS shelf to the OT. Another ascending region of $V_{\mathrm{p}}=5.5 \mathrm{~km} / \mathrm{s}$ contour is detected in the $\mathrm{OT}$ at distances of $\sim 150 \mathrm{~km}$ from the northwestern end of ECr8. To the southeast, some volcanic intrusions form a rugged topography and several active hydrothermal vents were located (Fig. 1). The Moho depth below the OT is estimated to be $20-22 \mathrm{~km}$. A Pn velocity of $8.2 \mathrm{~km} / \mathrm{s}$ for the northwestern margin of the OT is inferred from observed signals with a high apparent velocity on several OBS records (Additional file 1: Fig. A2). However, the high Pn velocity might 


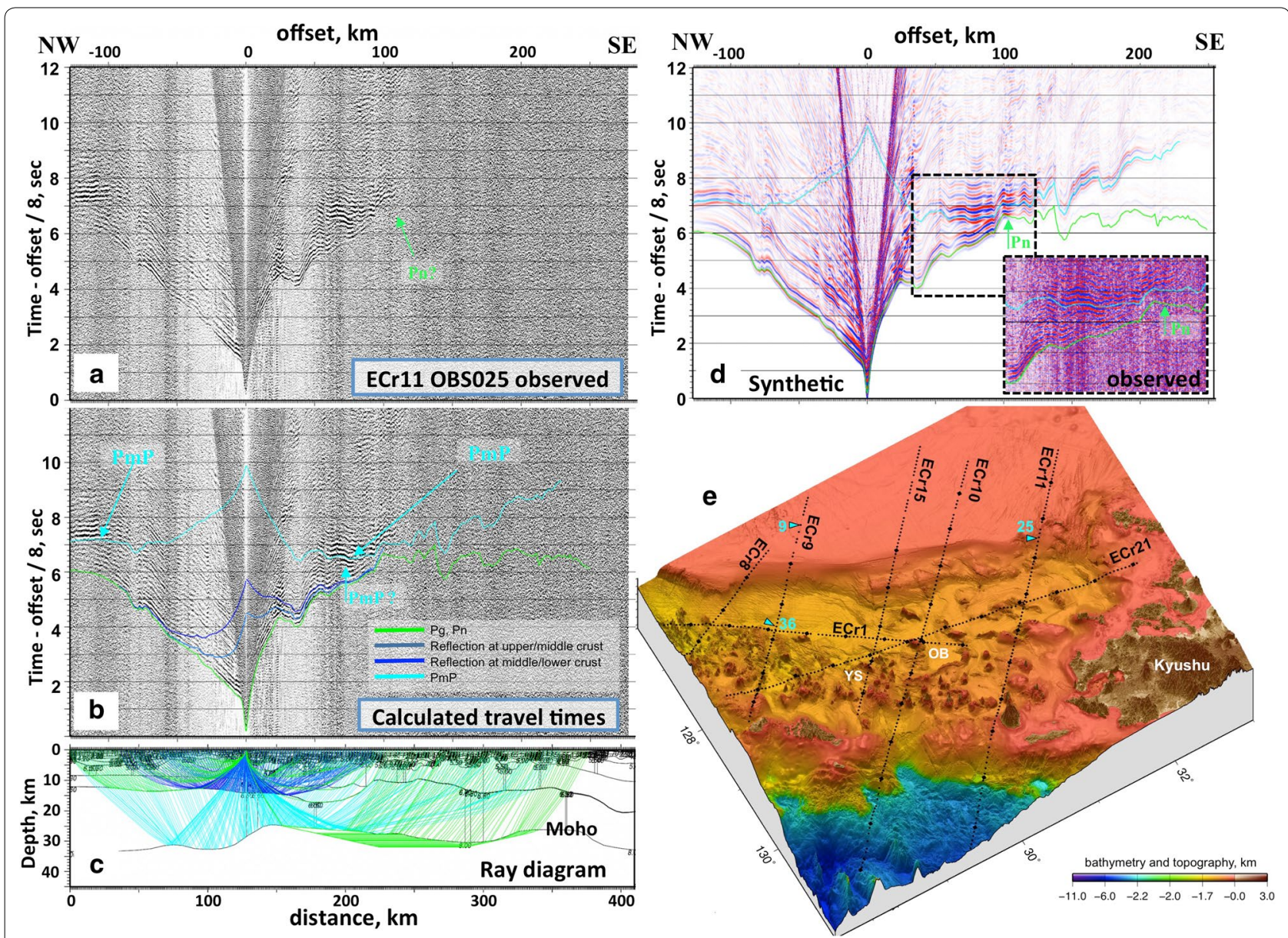

Fig. 7 Example of forward modeling for OBS025 on ECr11. a Observed record section, b calculated travel times on the record section, $\mathbf{c}$ ray diagram, $\mathbf{d}$ synthetic record sections with calculated travel times. Blowups of the observed weak Pn signals are also shown. Predictive deconvolution, 4-20 Hz bandpass filter, and a gain factor proportional to distance were used to increase signal-to-noise ratios of the observed record sections. The reduction velocity is $8.0 \mathrm{~km} / \mathrm{s}$. The color of the calculated travel times corresponds to the ray path in the ray diagram. The ray paths are generated at equal distance. e Positions of the seismic lines and ocean bottom seismographs (OBSs) on the three-dimensional topographic map. OB Okigaja Bank, YS Yokogan Sone

reflect three-dimensional heterogeneity because $\mathrm{ECr} 8$ is oblique to the strike of the seafloor topography. Below the OT, a slightly shallower Moho (2-3 km shallower) and Pn velocity of $7.9-8.0 \mathrm{~km} / \mathrm{s}$ were estimated based on the crossing seismic line of ECr1.

ECr7 is laid out on the boundary between the middle and southern OT, matching the extension of the Kerama Gap (Figs. 1, 2). The seafloor topography shows that the slope from the ECS shelf to the OT becomes steeper than that in the middle trough and has several submarine canyons. The MCS profiles (Fig. 4) reveal sedimentary basins with normal faults beneath the slope, similar to the northern profiles. The thickness of the sediments varies around the center of the trough with flat seafloor. The $V_{\mathrm{p}}$ model for ECr7 (Fig. 5) shows a thick middle crust below the ECS shelf, as inferred from travel times of reflections at the middle/lower crust boundary. The $V_{\mathrm{p}}$ distribution in the OT crust is rather homogeneous compared with the northern seismic lines. The Moho depth of over $25 \mathrm{~km}$ beneath the ECS shelf gradually becomes shallow, reaching $\sim 18 \mathrm{~km}$ below the trough. Although the crust is significantly thin beneath the OT, a continen$\mathrm{tal} /$ arc structure composed of an upper, middle, and lower crusts continues from the ECS shelf, through the OT to the Ryukyu Arc.

ECr16 is a seismic line with a north-south orientation in the southern OT. A characteristic elevation of the seafloor, the Taisho Bank, with a depth of 200-300 m exists at the western margin of the OT (Fig. 2). A deep sedimentary basin observed in the MCS profile (Fig. 4) reaches over $10 \mathrm{~km}$ deep between the ECS shelf and the 


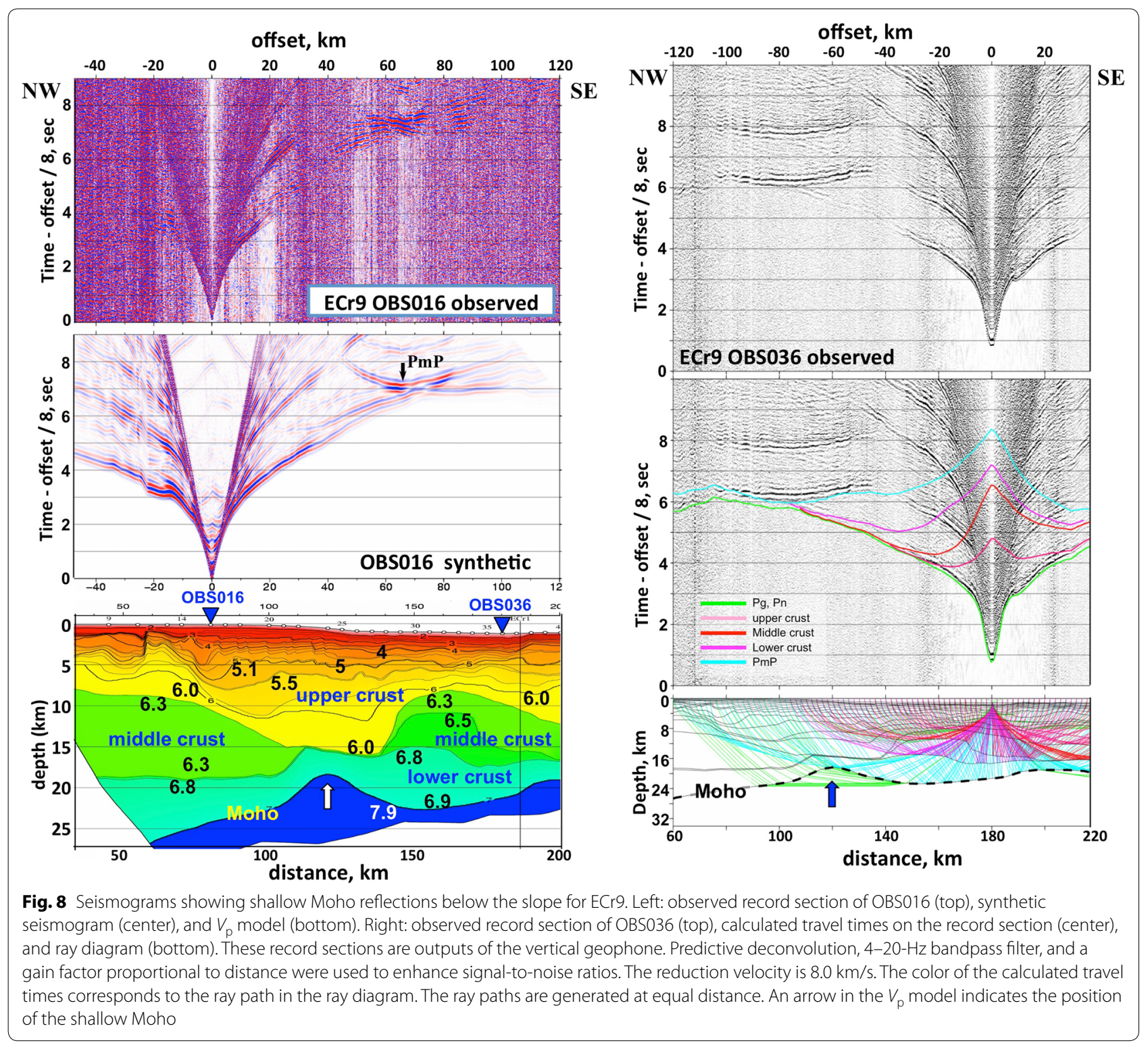

Taisho Bank. This feature corresponds to the wide distribution of materials with $V_{\mathrm{p}}<6 \mathrm{~km} / \mathrm{s}$ (Fig. 5). The $V_{\mathrm{p}}$ value of the Taisho Bank is not significantly different from that of the ECS shelf. The Miyako Rift, an elongate seafloor depression with a water depth of $2250 \mathrm{~m}$ at the center of the OT, corresponds to the depocenter of the uppermost sedimentary layer in the MCS profile (Fig. 4). The $V_{\mathrm{p}}$ distribution in the upper crust beneath the $\mathrm{OT}$ is more rugged beneath the northern side of the Miyako Rift. The Moho depth along ECr16 varies from $30 \mathrm{~km}$ below the ECS shelf to $\sim 17 \mathrm{~km}$ beneath the OT. The thinner crust below the trough is due to thinning of both the middle and lower crusts in the $V_{\mathrm{p}}$ model (Fig. 5). The estimated Pn velocity is $7.7-7.8 \mathrm{~km} / \mathrm{s}$.
ECr6 is positioned along the extension of the Miyako Saddle and intersects with ECr16 at the western margin of the Ryukyu Island Arc. The survey line was designed to cross the Miyako Rift, Miyako Seamount, and Daiichi-Miyako Knoll in the trough (Fig. 2). The MCS profile along ECr6 in Fig. 4 reveals a broad sedimentary basin with a width of $\sim 100 \mathrm{~km}$ beneath the ECS shelf. Although the bottom of the sedimentary basin is not clear, the $V_{\mathrm{p}}$ model in Fig. 5 shows that materials with $V_{\mathrm{p}} \leq 6 \mathrm{~km} / \mathrm{s}$ exist to a depth of $14-15 \mathrm{~km}$. There are sedimentary basins below the slope in the northwestern margin of the OT and to the north of Miyako Seamount. The latter sedimentary basin corresponds to the Miyako Rift, where several normal faults reach from the sea bottom to the 

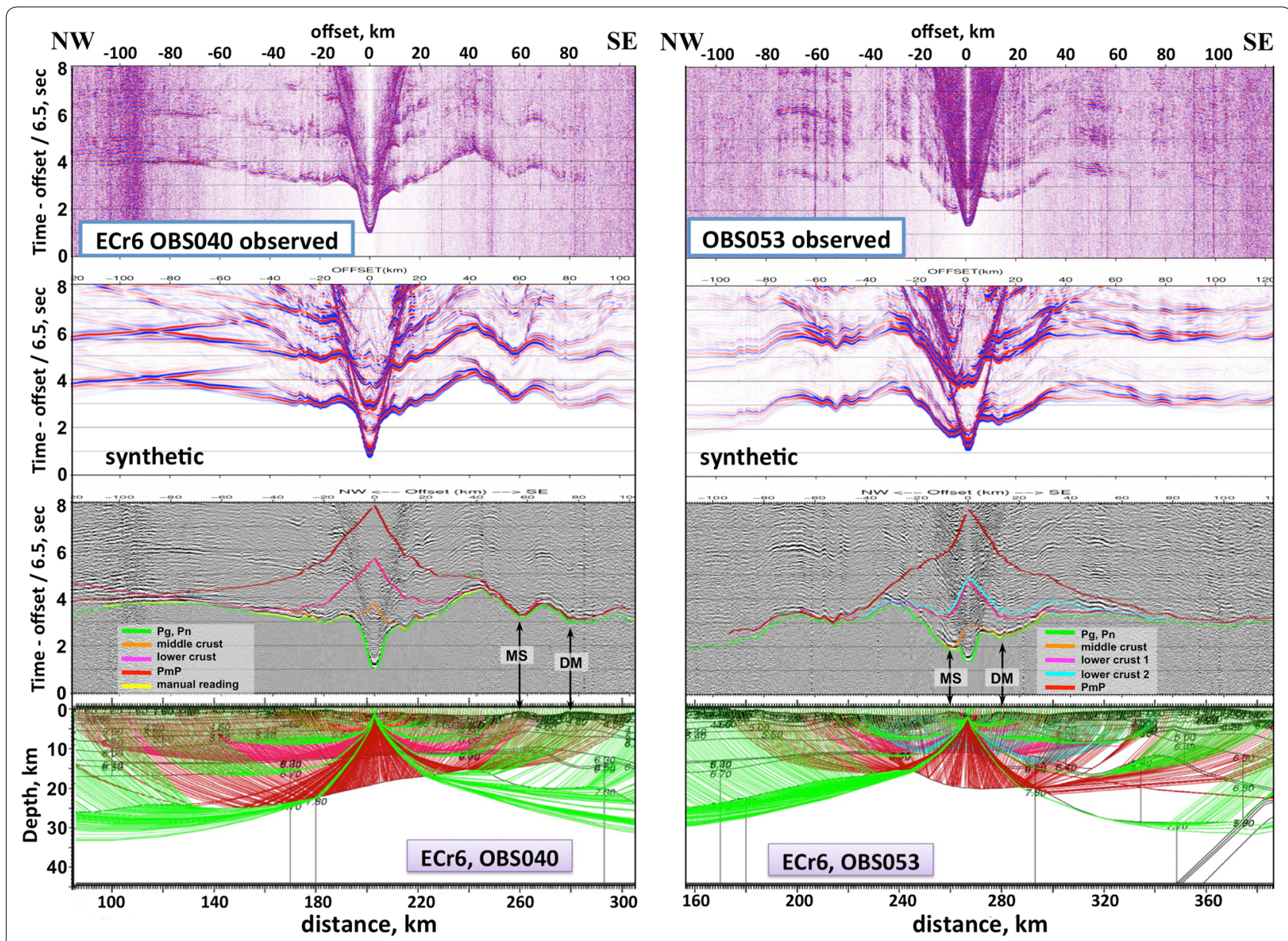

Fig. 9 Example of forward modeling for ECr6. From top to bottom, observed record sections, synthetic seismograms, and travel time fitting with ray diagrams for OBS040 (left) and OBS053 (right), respectively. The colors of the calculated travel times on the record sections correspond to the ray paths in the ray diagrams. The ray paths are generated at equal distance. The positions of the OBSO40 and OBS053 are indicated by blue inverse triangles in Fig. 2. DM Daiichi-Miyako Knoll, MS Miyako Seamount

acoustic basement below the rift. Two examples of travel time fitting and synthetic seismograms for OBS040 and OBS053 are shown in Fig. 9. Enlarged record sections are also shown in Additional file 1: Figs. A3 and A4. The calculated travel times and seismograms indicate good consistency with the observed record sections. $V_{\mathrm{p}}$ at the top of the Miyako Seamount is $\sim 4 \mathrm{~km} / \mathrm{s}$ and little sediment was detected, while over 1-km-thick materials with $V_{\mathrm{p}} \leq 4 \mathrm{~km} / \mathrm{s}$ covered Daiichi-Miyako Knoll (Fig. 5). The Moho depth gradually varies from $30 \mathrm{~km}$ at the northwestern end of ECr6 to $16 \mathrm{~km}$ at the Miyako Rift. The estimated Pn velocity is $7.7-7.8 \mathrm{~km} / \mathrm{s}$.

$\mathrm{ECr} 5$ traverses the Yaeyama Rift, the deepest area in the OT (Fig. 2). The MCS profile beneath the ECS shelf shows a broad and deep sedimentary basin corresponding to the region with $V_{\mathrm{p}} \leq 6 \mathrm{~km} / \mathrm{s}$, as observed in $\mathrm{ECr} 6$ (Figs. 4, 5). A smaller sedimentary basin exists below the transition area from the ECS shelf to the OT. There is a $\sim 100-\mathrm{km}$-wide, $\sim 5$-km-thick, and almost symmetric sedimentary basin around the center of the OT. Figure 10 shows that the synthetic seismogram for OBS038 at $\sim 10 \mathrm{~km}$ north of the Yaeyama Rift effectively explains the observed record section. The Yaeyama Knoll, about $200 \mathrm{~m}$ high in the Yaeyama Rift, shows a higher $V_{\mathrm{p}}$ than that of the surrounding sediments. The Moho depths are estimated to be $24-28 \mathrm{~km}$ for the ECS shelf and $12.5 \mathrm{~km}$, the shallowest value detected in this study, below the Yaeyama Rift. Pn velocity is $7.9 \mathrm{~km} / \mathrm{s}$.

ECr4 is the westernmost profile in our survey and crosses the Yonaguni Rift at the center of the OT (Fig. 2). There is a deep sedimentary basin deepening southward from the ECS shelf toward the OT (Fig. 4). The basin corresponds to materials with $V_{\mathrm{p}}<6 \mathrm{~km} / \mathrm{s}$ in the $V_{\mathrm{p}}$ model in Fig. 5. The seafloor topography in the OT is rather rough compared with that of ECr5, which may be explained by several intrusions at depths of 


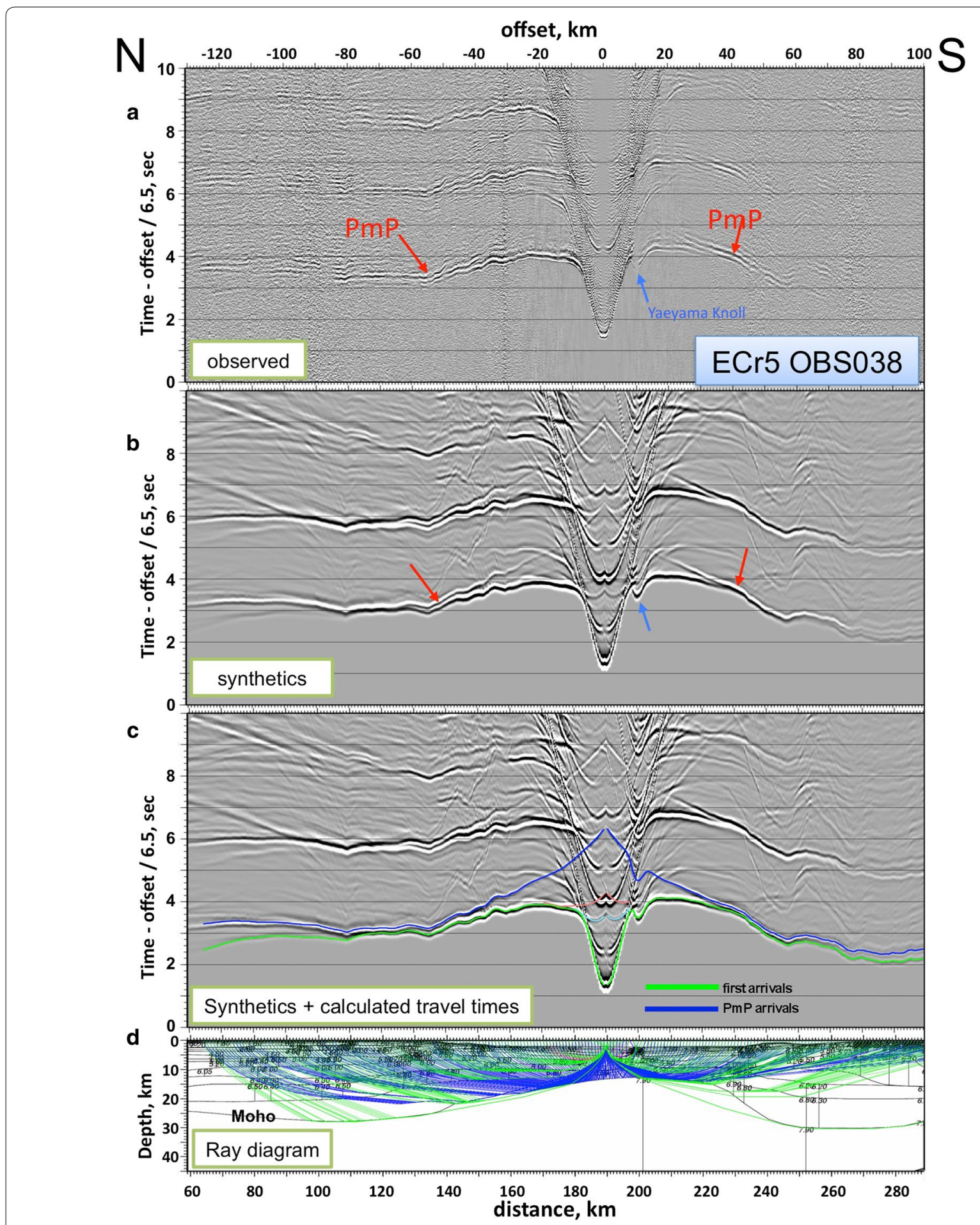

Fig. 10 Example of forward modeling for ECr5. a Observed record section of OBS038. Red arrows and blue arrows indicate PmP signals and refraction waves propagating through the Yaeyama Knoll, respectively. The position of the OBS038 is indicated by a red inverse triangle in Fig. $2 . \mathbf{b}$ Synthetic seismograms. c Calculated travel times on the synthetic seismograms. $\mathbf{d}$ Ray diagram. The ray paths are generated at equal distance 


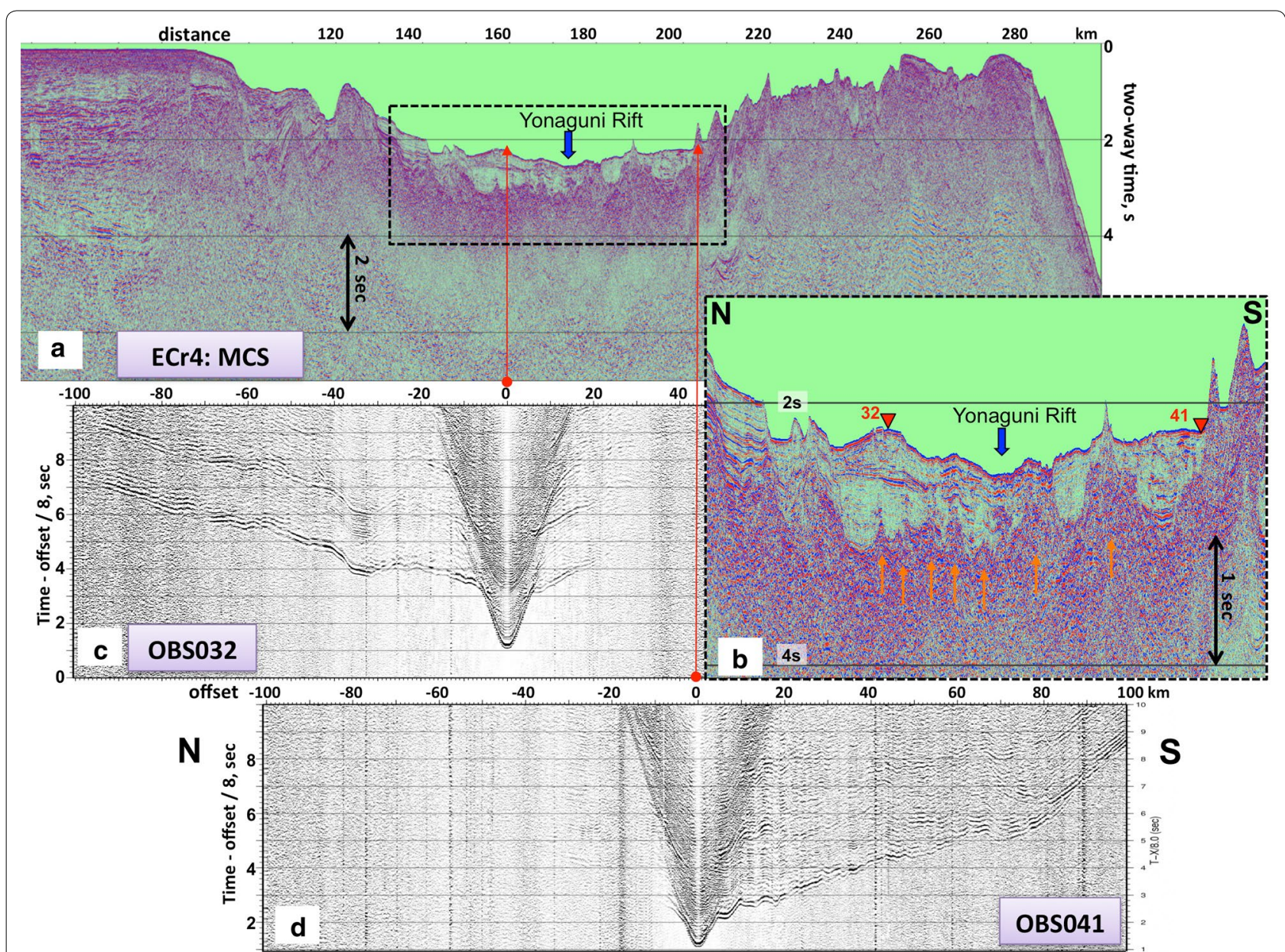

Fig. 11 a MCS time-migrated profile along ECr4 and $\mathbf{b}$ its blowup around the Yonaguni Rift. Up-arrows show the volcanic intrusions. Examples of record sections of $\mathbf{c} \mathrm{OBSO32}$ and $\mathbf{d} \mathrm{OBS041}$. These record sections indicate a strong attenuation zone to the south of the Yonaguni Rift

$2-3 \mathrm{~s}$ in the top sedimentary layer, as shown in Fig. 11a, b. As shown in the record sections in Fig. 11c, d, we could not detect signals at offset distances $>\sim 20 \mathrm{~km}$ for OBS032 and $<-10 \mathrm{~km}$ for OBS041, indicating very strong attenuation at distances of $170-210 \mathrm{~km}$ and depths of $5-10 \mathrm{~km}$ in the $V_{\mathrm{p}}$ model. The high attenuation suggests a source region of the volcanic intrusions. The middle crustal layer with a top velocity of $\sim 6 \mathrm{~km} / \mathrm{s}$ prevails along the survey line. The Moho depth varies from $\sim 27 \mathrm{~km}$ below the ECS shelf to $\sim 15 \mathrm{~km}$ beneath the Yonaguni Rift. Since we could not observe clear Pn arrivals, we roughly estimated Pn velocities of 7.6$7.7 \mathrm{~km} / \mathrm{s}$ using apparent velocities of reflection signals in the mantle. However, the reflectors in the upper mantle inferred using later arrivals on several OBS records might be the Moho discontinuity deviated from the seismic line due to three-dimensional structural heterogeneity (Additional file 1: Fig. A5).

\section{Along-trough lines}

ECr21 is a $563-\mathrm{km}$-long north-south trending line and traverses the northern half of the OT; the line starts from the continental shelf with a water depth of $\sim 200 \mathrm{~m}$ at the northern end, passes through the Danjo Basin and several topographic highs in the northwestern OT, and intersects the volcanic front at the southern end (Fig. 1). The water depth in the OT varies gradually from $700 \mathrm{~m}$ in the north to $1200 \mathrm{~m}$ in the south. As the seafloor topography varies substantially along the survey line, the seismic structure shows significantly inhomogeneous features. As shown in Fig. 12, there are many sedimentary basins and normal faults with various scales along the MCS profile. Three blowups of the MCS records reveal sedimentary basins between small bathymetric highs with high $V_{\mathrm{p}}$.

The $V_{\mathrm{p}}$ of the middle crust in the northern half of ECr21 is slightly slower than that in the southern half (Fig. 12). It is very difficult to divide the crust into upper 


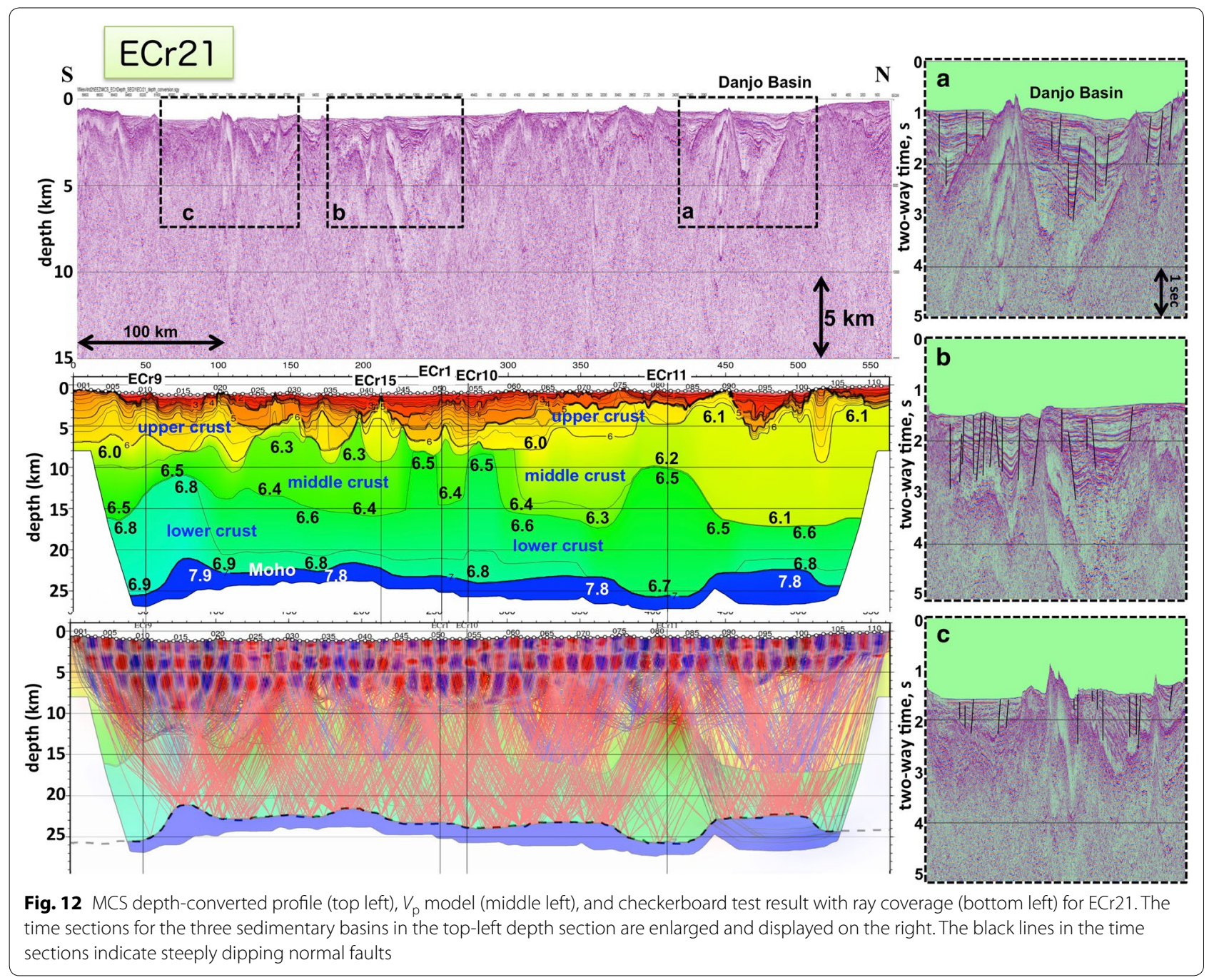

and middle crusts in the northern part of the survey line. A thick middle crust with a low $V_{\mathrm{p}}$ of $6.0-6.1 \mathrm{~km} / \mathrm{s}$ was modeled by interpreting observed later phases as reflections at the top of the lower crust. However, the $V_{\mathrm{p}}$ model could not explain all of the later arrivals and was not determined uniquely. The Moho depths are relatively uniform along ECr21, ranging from 21 to $26 \mathrm{~km}$, and do not show systematic variation over the profile. The deeper Moho at the southern end of ECr21 corresponds to the Ryukyu Arc. The estimated Pn velocity is $7.8-7.9 \mathrm{~km} / \mathrm{s}$.

ECr21 intersects with six seismic lines. The difference in the depths of the upper/middle crust boundary between ECr21 and ECr10 is likely due to the threedimensional heterogeneity of the local bathymetric high of Okigaja Bank (Fig. 12). The thickness of the middle crust largely varies along ECr21 and $\sim 5 \mathrm{~km}$ thicker than that of ECr15 at the intersection. The Moho depth of $27 \mathrm{~km}$ inferred from PmP arrivals at the southern end of ECr21 is deeper than the depth of $23 \mathrm{~km}$ for ECr9. Both
Moho depths were estimated at the ends of the survey lines with large topographic irregularities and are difficult to determine accurately. There are no other significant discrepancies between these $V_{\mathrm{p}}$ models.

$\mathrm{ECr} 1$ is the longest survey line with a length of $710 \mathrm{~km}$ in our survey and passes a relatively deepwater area along the OT. The water depth along ECr1 generally increases from north to south and reaches the deepest part around its southwestern end. There are several kinds of deformation patterns seen at shallow depths, including the significant undulation of the acoustic basement and normal faulting (Fig. 13). Despite that there are many normal faults in the sedimentary basins to the southwest of Okigaja Bank, little seafloor deformation is recorded in the MCS images and the seafloor topography is flat. A slightly rough seafloor topography around the Iheya Knolls corresponds to several intrusions. The upper crustal thickness varies along the profile. The Moho depth gradually decreases from north to south. 


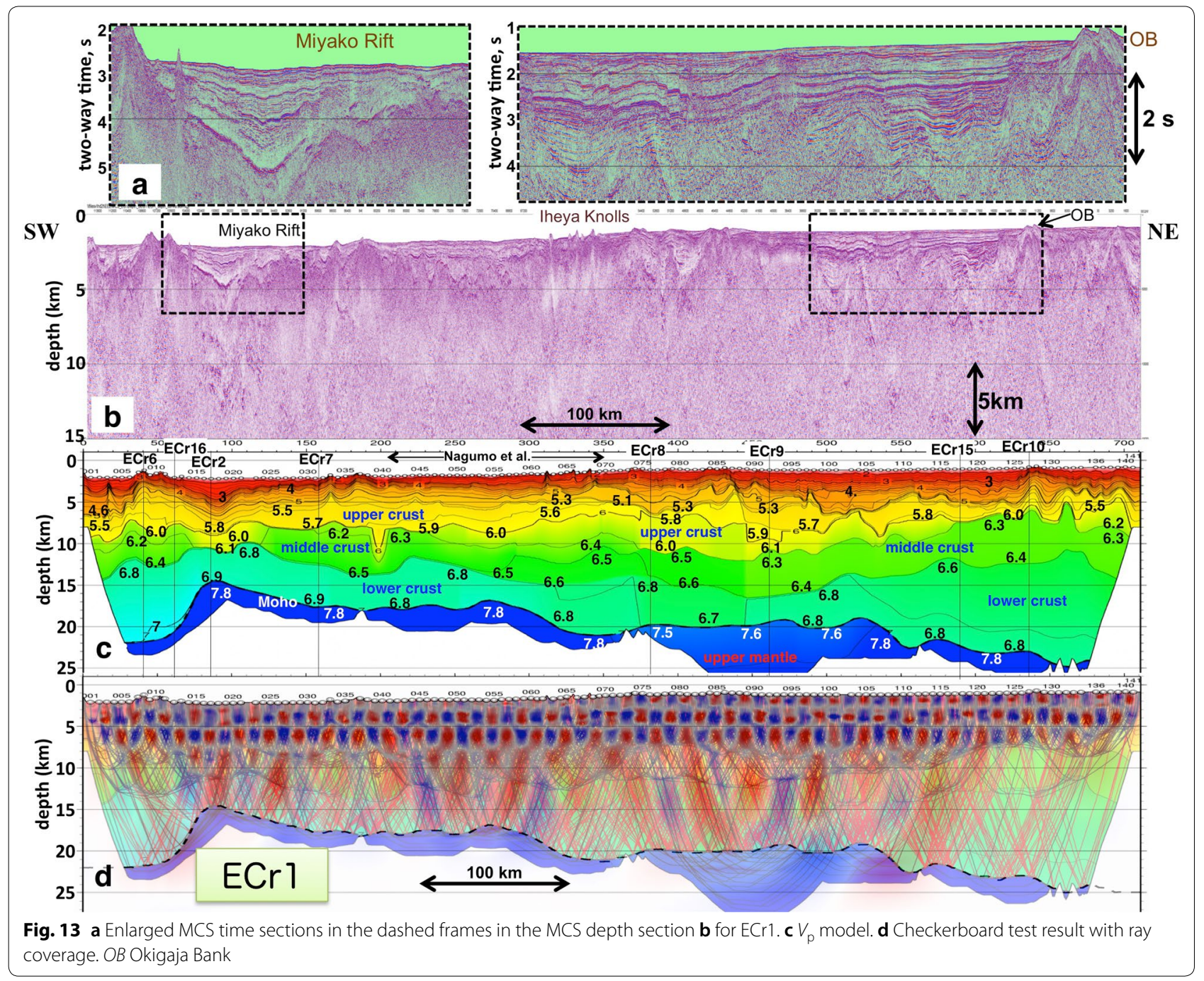

The thinnest crust was detected beneath the Miyako Rift; the Moho depth is $\sim 15 \mathrm{~km}$, where $V_{\mathrm{p}}$ of the middle crust is lower, and the lower crust is thinner than that of the surroundings. The estimated Pn velocity is $7.5-7.8 \mathrm{~km} / \mathrm{s}$ and lower northeast of Iheya Knolls, where the layer with $V_{\mathrm{p}} \leq 6 \mathrm{~km} / \mathrm{s}$ is slightly thicker than the surroundings.

ECr1 intersects with seven across-trough survey lines (Fig. 1). ECr1 crosses ECr10 at the foot of the bathymetric high of Okigaja Bank. Their $V_{\mathrm{p}}$ models show good consistency, despite inhomogeneity of the seafloor topography. The velocity in the middle crust for ECr1 is $0.2 \mathrm{~km} / \mathrm{s}$ higher than that for ECr15. ECr1 has a consistent $V_{\mathrm{p}}$ structure with ECr9, except for the Pn velocity, $7.9 \mathrm{~km} / \mathrm{s}$ for ECr1 and $7.6 \mathrm{~km} / \mathrm{s}$ for ECr9. Similarly, a significant difference at the intersection with $\mathrm{ECr} 8$ is that the Pn velocity of ECr1 varies from $7.5 \mathrm{~km} / \mathrm{s}$ in the northeast to $7.8 \mathrm{~km} / \mathrm{s}$ in the southwest, while that for ECr8 is $\sim 8 \mathrm{~km} / \mathrm{s}$. Although the depths of each crustal part and Moho are consistent with those of ECr7, the velocities differ by a maximum of $0.3 \mathrm{~km} / \mathrm{s}$. There is no significant difference between ECr1 and ECr16 at the intersection. The depths of the middle crustal layer and Moho for ECr1 differ from those for ECr6 by 1-2 km.

ECr2 passes around the center of the southern OT and traverses the Yonaguni Rift and the Yaeyama Rift in the southwestern part of the line (Fig. 2). The seismic line also goes through some nameless immature rifts, small-scale depressions shallower than the aforementioned two rifts by $100-200 \mathrm{~m}$, in the northeastern part. The seafloor in these rifts is deeper by several tens to hundreds of meters than the surrounding areas. Figure 14 provides the MCS profile and blowups of these rifts, showing many normal faults and intrusions in the sedimentary layer. The base of the sediments is lifted up by the intrusions. They may be volcanic intrusions associated with the crustal thinning under the backarc 


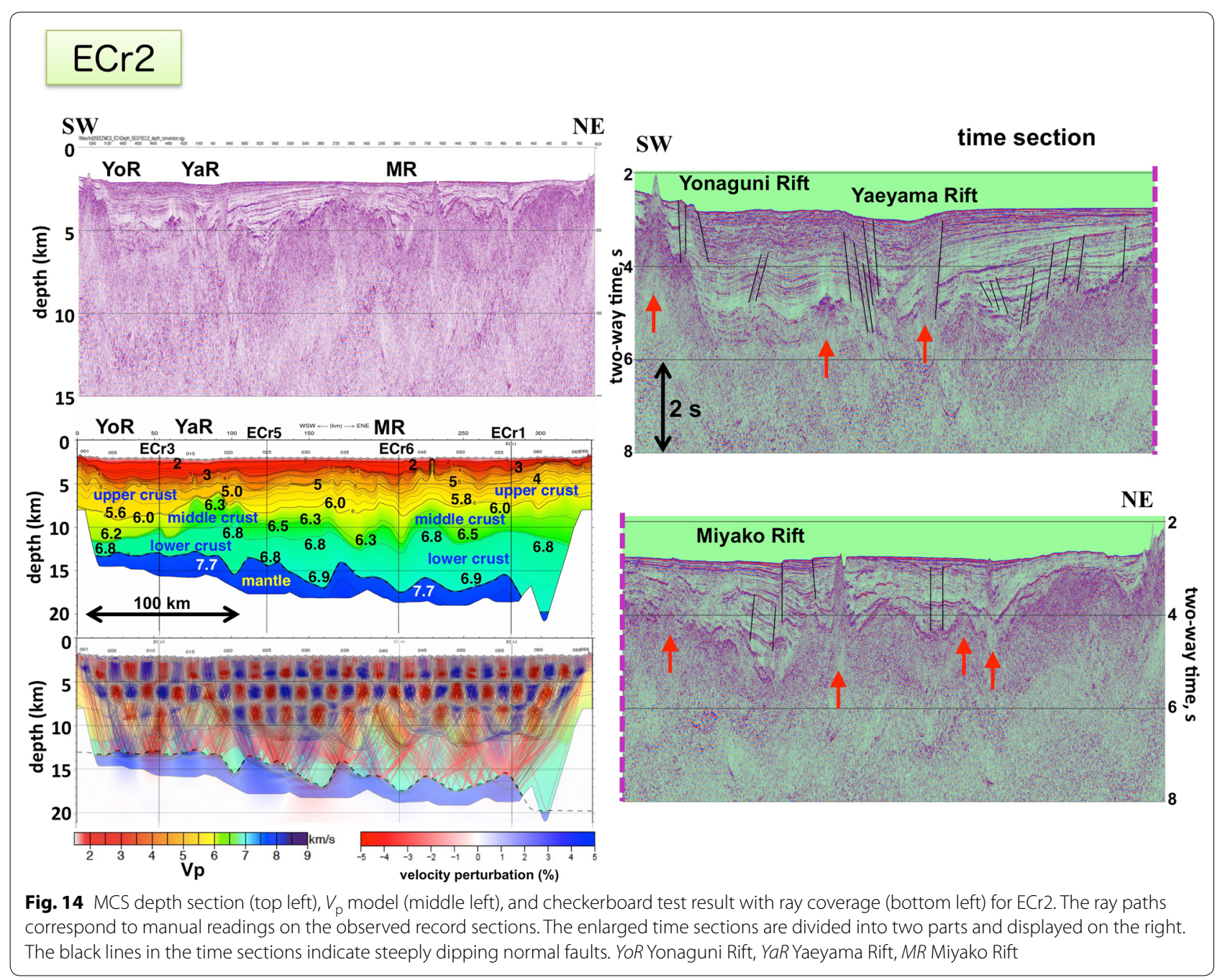

extension. The $V_{\mathrm{p}}$ distribution in the upper and middle crust between these rifts is not the same, and the materials with $V_{\mathrm{p}}=6.3 \mathrm{~km} / \mathrm{s}$ are shallower beneath the Yaeyama Rift. The crust is composed of an upper, middle, and lower crusts prevailing along the seismic line. The Moho depth along the ECr2 is slightly rugged as a result of better travel time fitting of PmP arrivals, as confirmed by a comparison with the two-dimensional synthetic seismograms calculated by E3D. However, this may reflect the three-dimensional irregularity of the Moho discontinuity. The Moho depth generally deepens from SW to NE and is shallow, $17 \mathrm{~km}$, below the Yonaguni Rift and the Yaeyama Rift. The Pn velocity is estimated to be $7.7 \mathrm{~km} / \mathrm{s}$ along the line.

ECr2 intersects with four across-trough survey lines (Figs. 1, 2). The crustal models for ECr2 and ECr5 are highly similar, despite a difference in the uppermost mantle velocity of $\sim 0.2 \mathrm{~km} / \mathrm{s}$. Compared with ECr6, the Moho on ECr2 is $1 \mathrm{~km}$ deeper. The ECr16 crustal model shows good consistency with the ECr2 model. The $V_{\mathrm{p}}$ model for ECr2 is approximately consistent with the ECr1 and shows $\sim 0.2 \mathrm{~km} / \mathrm{s}$ lower velocities in the middle and lower crusts.

\section{Along-rift or rift-parallel lines in the southern Okinawa Trough}

Figure 15 summarizes the MCS profiles, $V_{\mathrm{p}}$ models, and checkerboard test results with ray coverage for the survey lines parallel to en echelon submarine rifts characterizing the seafloor topography in the southern OT (Fig. 2).

ECr22 is located along the center of the Miyako Rift with water depths of $\sim 2200 \mathrm{~m}$. The MCS profile in Fig. 15 shows several intrusions in the sedimentary basin. The shallowest Moho depth is $\sim 15 \mathrm{~km}$ at the transition from the rift to Daisan-Miyako Knoll. The estimated Pn velocity below the rift is $7.7-7.8 \mathrm{~km} / \mathrm{s}$. The crust beneath the rift is also composed of upper, middle, and lower crusts, indicating an island arc structure. Although ECr22 is only 


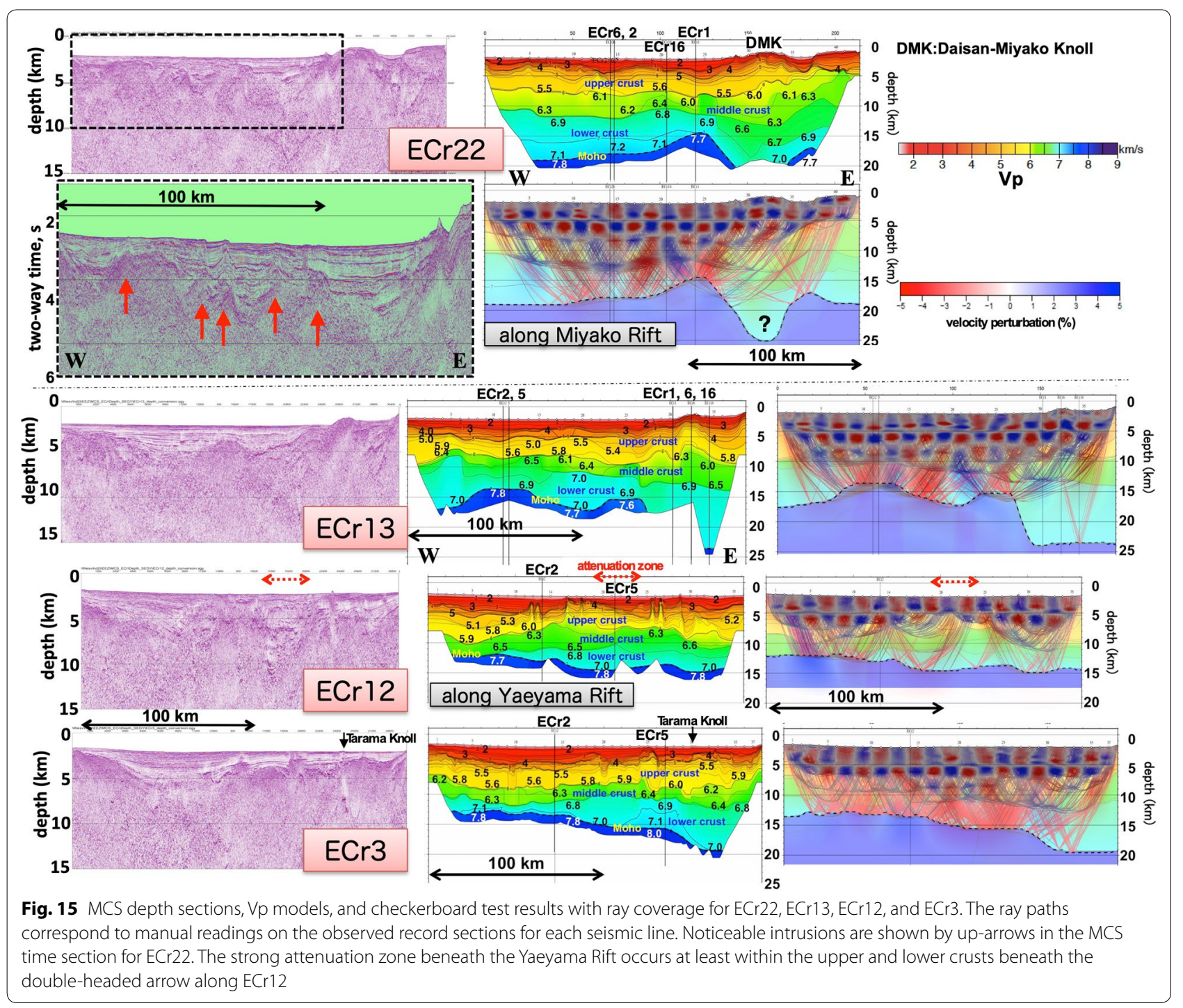

$213 \mathrm{~km}$ long and shorter than other lines, it crosses four lines. $V_{\mathrm{p}}$ models for $\mathrm{ECr} 22$ and $\mathrm{ECr} 1$ are consistent at the intersection. The Moho depth for ECr22 is $\sim 2 \mathrm{~km}$ deeper, and the $V_{\mathrm{p}}$ at the base of the lower crust is $\sim 0.2 \mathrm{~km} / \mathrm{s}$ higher than that of ECr6. The $V_{\mathrm{p}}$ at the lower crust for $\mathrm{ECr} 22$ is $\sim 0.2 \mathrm{~km} / \mathrm{s}$ higher than that for ECr2. ECr22 intersects with ECr16 in the Miyako Rift, and their $V_{\mathrm{p}}$ models are consistent.

ECr13 is parallel to the Yaeyama Rift on the north side. The horizontal distance from the center of the rift is $\sim 15 \mathrm{~km}$, the water depth is $\sim 2000 \mathrm{~m}$, and it is mostly flat. The bathymetric high in the east belongs to a foot of the Daiichi-Miyako Knoll (Fig. 2). The MCS profile in Fig. 15 reveals several volcanic intrusions cutting and lifting up acoustic basements in the sedimentary layer. The relatively clear signals reflected at the upper-middle crust boundary were observed in several OBS record sections (e.g., Additional file 1: Fig. A6). The Moho depth is 13-17 km, except for $>20 \mathrm{~km}$ at the eastern end of the line near the Ryukyu Arc. Pn velocity is 7.6-7.7 km/s.

ECr13 intersects with ECr2 and ECr5 on the almost same point to the north of the Yaeyama Rift (Fig. 2). The difference among the $V_{\mathrm{p}}$ models is that ECr5 has higher velocities at the base of the crust and the uppermost mantle by $0.2 \mathrm{~km} / \mathrm{s}$. ECr13 also crosses with ECr1, ECr6, and ECr16 on Daiichi-Miyako Knoll. The $V_{\mathrm{p}}$ models are approximately consistent except that the base of the middle crust for ECr13 is deeper than that of ECr6 by $3 \mathrm{~km}$.

ECr12 is located along the center of the Yaeyama Rift. The seafloor is nearly flat, and water depths are generally 2200-2300 m. Many volcanic intrusions were detected in the MCS profile, and they have higher $V_{\mathrm{p}}$ in the 
sedimentary layers than those of the surrounding areas (Fig. 15). An attenuation zone with a width of $\sim 25 \mathrm{~km}$ in the upper and middle crust, shown by a double arrow in Fig. 15, was inferred from invisible refraction signals in the OBS record section (Additional file 1: Fig. A7). Same as ECr4 in Fig. 11, the attenuation may relate to the source region of the volcanic intrusions observed in the MCS record. Although reflections from the middle and lower crust boundary were detected at the center of ECr12, $V_{\mathrm{p}}$ for the lower crust was not determined due to a lack of rays of refracted waves, as shown in the ray diagram in Fig. 15. The shallowest Moho is expected below the center of the line, with the deepest water of $\sim 2300 \mathrm{~m}$, but it is found at the western end of the line where there is no layer with a $V_{\mathrm{p}}$ indicating an arc lower crust. $\mathrm{ECr} 12$ traverses ECr2 obliquely in the Yaeyama Rift (Fig. 2), and its crustal $V_{\mathrm{p}}$ shows slower than that of the ECr2 model. The $V_{\mathrm{p}}$ model for ECr12 is significantly different from the ECr5 model in the deeper part with $V_{\mathrm{p}}>3.0 \mathrm{~km} / \mathrm{s}$ due to irregularities related to the Yaeyama Knoll.

$\mathrm{ECr} 3$ is designed to be parallel to the Yaeyama Rift on the south side where the water depth is $2000-2100 \mathrm{~m}$, excluding the western part. Although the seafloor is flat, the distribution of sedimentary basins varies along the MCS profile (Fig. 15). The number of intrusions is larger than that of ECr13. Tarama Knoll is one of the intrusions which is known to host a hydrothermal vent (Yamanaka et al., 2015). There is not distinct variation in the $V_{\mathrm{p}}$ model around the Tarama Knoll, except for a slightly shallower velocity contour of $4 \mathrm{~km} / \mathrm{s}$ where several intrusions are observed in the MCS profile. The upper crust with a thickness of $\sim 5 \mathrm{~km}$ prevails along the survey line. The Moho deepens from $13 \mathrm{~km}$ in the west to $19 \mathrm{~km}$ toward the Ryukyu Arc in the east. The thickness of the crust is $10-15 \mathrm{~km}$, excluding the upper sedimentary layer. A Pn velocity of $7.8-8.0 \mathrm{~km} / \mathrm{s}$ is obtained. The $V_{\mathrm{p}}$ model for ECr3, as a whole, consists of upper, middle, and lower crusts.

ECr3 intersects with three seismic lines (Fig. 2). The crustal $V_{\mathrm{p}}$ models for $\mathrm{ECr} 3$ and $\mathrm{ECr} 4$ at the intersection are not significantly different. The Moho for ECr3 is shallower than that for ECr 5 by a $3 \mathrm{~km}$, indicating substantial heterogeneity in deeper crust around the intersection area. The $V_{\mathrm{p}}$ values in the middle and lower crust for ECr3 are $\sim 0.2 \mathrm{~km} / \mathrm{s}$ higher than those of ECr2; the values for $\mathrm{ECr} 2$ are lower, potentially because $\mathrm{ECr} 2$ passes the Yaeyama Rift and Yonaguni Rift near the intersection where crustal thinning and fracturing go on.

\section{Discussion}

\section{Northern Okinawa Trough}

The seismic structure in the northern OT obtained from across-trough lines, ECr11, ECr10, and ECr15, and along-trough lines, ECr21 and ECr1, shows large inhomogeneity in both directions. However, the crustal models generally show thinned continental/arc crusts of the ECS shelf and the Ryukyu Island Arc, which consists of upper $\left(V_{\mathrm{p}}<6 \mathrm{~km} / \mathrm{s}\right)$, middle $(6.0-6.5 \mathrm{~km} / \mathrm{s})$, and lower crusts $(>6.5 \mathrm{~km} / \mathrm{s})$. Higher velocity materials than the surroundings in the shallow crust are ascending below the bathymetric highs near the volcanic front (Fig. 5). However, such feature is not observed beneath Okigaja Bank and Yokogan Sone, indicating their possible origin of fragments as the Ryukyu Arc.

The $V_{\mathrm{p}}$ models in the northern OT were previously presented by Iwasaki et al. (1990) and Nakahigashi et al. (2004). The positions of their seismic lines are plotted in Fig. 1. They classified the crust into two parts, upper and lower crusts. They indicated that the layer with $V_{\mathrm{p}}=5.7-6.2 \mathrm{~km} / \mathrm{s}$ in the upper crust, corresponding to our upper and middle crust, becomes thin from north to south, despite a lower crust with a constant thickness along the northern OT. They suggested that this is the characteristic incipient stage of backarc rifting in this region. Despite the close position of ECr21 to the seismic line of Nakahigashi et al. (2004), the $V_{\mathrm{p}}$ and thickness of the middle crust within the $V_{\mathrm{p}}$ range of $6.0-6.5 \mathrm{~km} / \mathrm{s}$ largely vary along ECr21 and the thickness of the lower crust with $V_{\mathrm{p}}=6.5-6.9 \mathrm{~km} / \mathrm{s}$ also varies. Since our results were derived from a larger number of OBSs and MCS channels, we could obtain a more detailed seismic image of the crust along ECr21. However, the positions of the two lines are not the same, and there are more bathymetric highs on ECr21 compared with the rather flat sea bottom along the line of Nakahigashi et al. (2004), which may explain the differences between the $V_{\mathrm{p}}$ models. Along ECr1, the southwestward extension of ECr21, the crustal thickness gradually decreases toward the southwest, and the lower crust, but not the upper/middle crusts, seems to be thinning (Fig. 13). Therefore, it is not easy to conclude that the crustal thinning due to the rifting of the northern OT is concentrated in the upper/middle crust.

The shallowest Moho along ECr11 was estimated beneath the northwestern margin of the OT. Although large earthquakes with $M \geq 7$ were not recorded in the OT, except for the 1938 M7.2 earthquake in the southern OT, the Satsuma-hanto Seiho-oki Earthquake with a magnitude of 7.1 struck at the western margin of the OT on November 14, 2015 and caused a tsunami with a height of $30 \mathrm{~cm}$ at Nakanoshima on Tokara Islands (Fig. 16). According to the report by the Japan Metrological Agency (JMA), the earthquake had a strike-slip mechanism with an extension axis in the northwestsoutheast direction and occurred in the continental crust. Aftershock epicenters of the Satsuma-hanto 


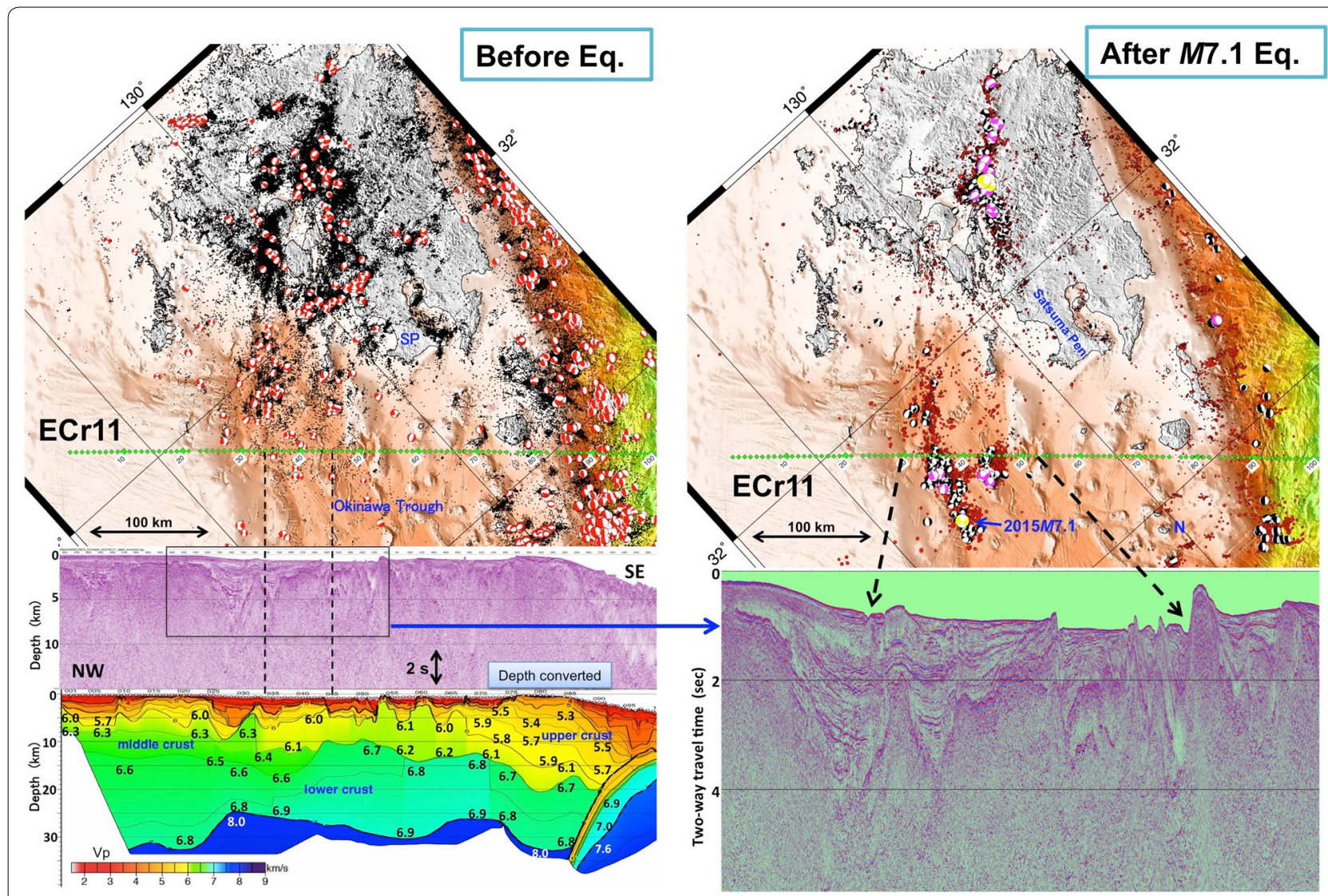

Fig. 16 (Top left) Epicenter distribution before the Satsuma-hanto Seiho-oki Earthquake (M7.1) on November 14, 2015. Black dots show epicenters with depths shallower than $30 \mathrm{~km}$ as determined by the Japan Metrological Agency (1923-2015, November 14). Focal mechanisms are from the F-net CMT Catalog by the National Research Institute for Earth Science and Disaster Resilience (depth $\leq 30$ km, 1997-2015, November 14). The locations of the OBSs on ECr11 in the northernmost OT are indicated by green squares. The MCS profile (depth-converted section) and $V_{p}$ model along ECr11 are shown on the center and bottom left. The $V_{p}$ of the middle crust between two broken lines is slightly slower than both sides. (Top right) Epicenter distribution of the M7.1 earthquake and their aftershocks (depth $\leq 30$ km, 2015, November 14-2017, May 2). CMT mechanisms, yellow, $M \geq 6$; pink, $M \geq 5$. A tsunami with a height of $30 \mathrm{~cm}$ caused by the $M 7.1$ earthquake was observed at Nakanoshima island shown by $N$ in the map. The MCS time section across the aftershock area is enlarged on the bottom right

Seiho-oki Earthquake were distributed along the transition zone between the ECS shelf and the OT (Fig. 16). Although the mechanisms of these aftershocks are two types, strike-slip and normal fault type, both of them have extension axes with the northwest-southeast direction. The extension axis of the main shock is also northwest-southeast direction. The MCS profile shows many normal faults in the aftershock area, and $\mathrm{P}$ wave velocity model reveals that the shallow part of the middle crust has a slightly lower velocity. These characteristics indicate deformation of the crustal structure under the present rifting tectonics.

\section{Middle Okinawa Trough}

A distinctive characteristic of the $V_{\mathrm{p}}$ models in the Middle OT is a broad and deep area with $V_{\mathrm{p}} \leq 6 \mathrm{~km} / \mathrm{s}$ distributed beneath from the ECS shelf to the OT. The distribution of the materials with $V_{\mathrm{p}}$ lower than that of a typical middle crust seems to correspond to the lower free-air gravity anomalies in Fig. 3a. The very thin or lack of a typical middle crustal layer indicates that the $V_{\mathrm{p}}$ of the middle crust decreases to $\sim 6.0 \mathrm{~km} / \mathrm{s}$ for various potential reasons, such as deformation, fracturing, and volcanic intrusions. The shallowest Moho for ECr9 is obtained beneath the slope at the northwestern margin of the OT, similar to that for ECr11, suggesting that there are active crustal deformations in the rifting process in this area.

Nagumo et al. (1986) conducted a seismic refraction experiment named DELP 1984 using explosives as a controlled seismic source in the region between ECr8 and ECr7 (blue lines with D in Fig. 1), and they showed 


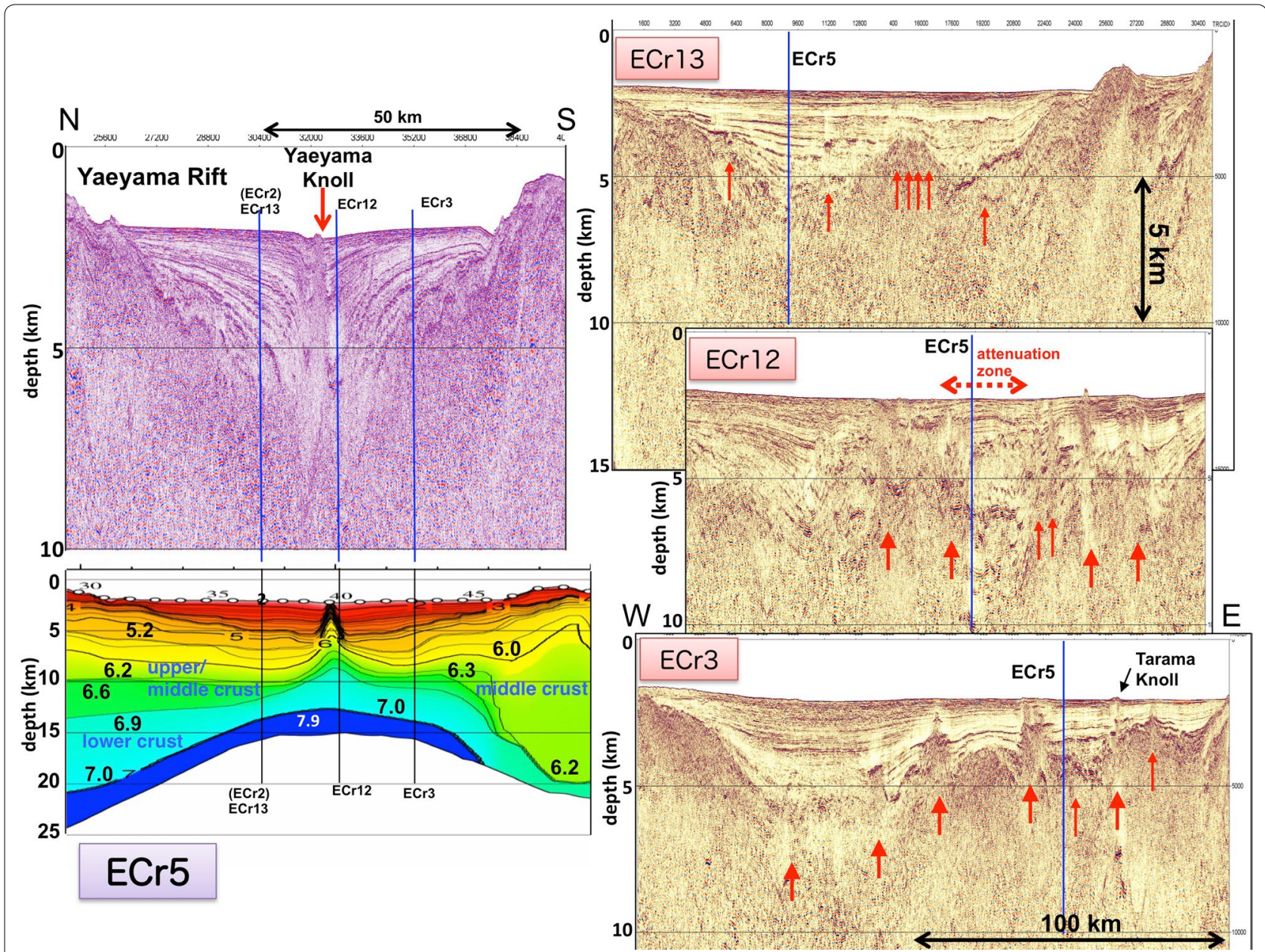

Fig. 17 Comparison of the MCS profiles (depth section) perpendicular and parallel to the Yaeyama Rift. Left: Across-rift line ECr5. $V_{p}$ model around the rift is also shown. Right: MCS depth profiles for rift-parallel lines of ECr13, ECr12, and ECr3. Noticeable volcanic intrusions are shown by up-arrows. Smaller arrows indicate small-scale intrusions. More and larger intrusions were detected along ECr13 compared with ECr3, indicating an asymmetric seismic structure across the rift axis

the crust has a $6.0 \mathrm{~km} / \mathrm{s}$ layer at depths of $5-10 \mathrm{~km}$ and lower crustal layer with a $V_{\mathrm{p}}$ of $6.8 \mathrm{~km} / \mathrm{s}$ and significant attenuation. The position of their survey lines is approximately $200-350 \mathrm{~km}$ from the southwestern end of ECr1 (Fig. 13c). Our crustal $V_{\mathrm{p}}$ in this area is significantly different from that reported by Nagumo et al. (1986), and this difference may be explained by a more precise estimation of the shallower structure with low velocities in our model.

The Moho depths below the OT for the across-trough lines of ECr9 and ECr8 are $20-23 \mathrm{~km}$ and are thinner than those of the northern OT. The $V_{\mathrm{p}}$ model for ECr1 (Fig. 13c) shows that the Moho depth along the middle OT roughly decreases from 23 to $18 \mathrm{~km}$ southwestward. These results indicate the crustal thinning is more progressed in the middle OT.

\section{Southern Okinawa Trough}

The crustal thinning due to rifting is progressing clearly in the southern OT. We designed ten seismic lines in this region to obtain seismic images beneath the rifts with the thinnest crust over the OT. The $V_{\mathrm{p}}$ models of the acrosstrough lines are almost symmetric about the trough axis (Fig. 5). The shallowest Moho for each across-trough line is located beneath the rifts around the center of the OT with the deepest water, unlike the northern and the middle OT.

The shallowest Moho in our study is $12.5 \mathrm{~km}$ from the sea surface in ECr5 (Fig. 17), where the crustal thickness is $\sim 10 \mathrm{~km}$ including the top sedimentary layer (or $\sim 7 \mathrm{~km}$ without sediment). Although Hirata et al. (1991) estimated that the Moho depth is $18 \mathrm{~km}$ and the crustal thickness is $16 \mathrm{~km}$ along almost the same seismic line 
as ECr5, their model should be revised according to our ECr5 model determined using a large amount of data with more OBSs and longer survey lines. We could not determine whether the $V_{\mathrm{p}}$ model of the Yaeyama Knoll in the Yaeyama Rift is typical oceanic crust due to the small scale of the knoll. The higher $V_{\mathrm{p}}$ in the shallower part indicates a young (less than $1 \mathrm{Ma}$ ) volcanic ridge, as estimated by Ishikawa et al. (1991).

The thinnest crust of $\sim 7 \mathrm{~km}$ for ECr 5 is slightly thicker or comparable with 4-7 km of the Shikoku Basin and the West Philippine Basin, inactive backarc basins east of the OT (Nishizawa et al. 2011, 2014) and 5-6 km of the active Mariana Basin, south of Japan (Takahashi et al. 2008). Although these backarc basins do not have middle crust same as a typical oceanic crust, the thinned crusts of the OT are composed of the upper, lower, and middle crust from the ECS shelf, through the OT, to the Ryukyu Island Arc.

Arai et al. (2017) conducted a high-spec seismic exploration across the Yaeyama Rift near ECr5 (line A in Fig. 1) and revealed the thinnest crust (12 km thick) including top sediments below the rift axis. They suggested that the southern OT is still in a transitional stage from continental rifting to seafloor spreading based on the crustal model as well as magnetic and petrological data. Our results are comparable with these previous results and further show the continuity of the continental/island arc crust from the ECS shelf to the Ryukyu Arc. Because of a very thin crust with a similar thickness to a typical oceanic crust in the Xihu Depression, a kind of paleobackarc basin (Li et al. 2009) currently buried with thick sediments, we cannot predict the future oceanic spreading in the OT.

A nearly symmetric image of the Yaeyama Rift in the MCS profile was obtained by Arai et al. (2017). They showed that the rift structure includes a narrow (2-7 km wide) on-axis intrusion resulting from a passive upwelling of magma and detected a low-velocity magmatic body at a depth of $4 \mathrm{~km}$ from the seafloor to the east of the intrusion by tomographic inversion. We similarly obtained seismic images of the Yaeyama Rift along ECr5, as shown in Fig. 17. Moreover, three MCS profiles that intersect with ECr5 and are parallel to the Yaeyama Rift are shown to evaluate the symmetric property of the rift structure. The MCS profile for ECr12 in the rift reveals many complex intrusions, and there are more intrusions in ECr3 to the south of the rift than in ECr13 to the north. Therefore, the rift structure is not necessarily symmetric based on a detailed analysis of the seismic data. The MCS records in the northern Ryukyu Arc showed numerous volcanic conduits within the sedimentary basins and shallow crust around the volcanic front (Arai et al., 2018). Therefore, more abundant intrusions to the south of the rift suggest the existence of a magmatic body related to the invisible volcanic front in the southern OT.

Figure 18 shows the shallow seismicity with a hypocentral depth of $\leq 30 \mathrm{~km}$ with the fine bathymetric map. The accuracy of hypocenter locations is poorer than that in land areas in Japan due to the sparse NIED (National Research Institute for Earth Science and Disaster Resilience) seismic stations around the OT, and there is a significant difference in the distribution of CMT mechanisms obtained by NIED and that of Global CMT, especially around Miyako Seamount. However, it is interesting to compare the epicenter distribution with the seismic structure. The epicenter distribution is spatially inhomogeneous and shows several clusters. The detailed bathymetric map demonstrates that active seismic areas correspond to characteristic seafloor features. For instance, three small epicenter clusters in the east of the Yaeyama Rift coincide with the position of volcanic intrusions on the seafloor and are also detected in the MCS profile for ECr12 (Fig. 18), although they are not separated clearly. Also, the seismically active area at the southwestern end of the OT shows a southwest-northeast strike and has slightly deeper water than the surroundings, connecting the two rifts of the Yonaguni Rift and the Yaeyama Rift. The strike of the active seismicity is same as the direction connecting the eastern end of the Yaeyama Rift and Miyako Seamount, where the seafloor is also slightly deeper and epicenters determined by JMA are concentrated. The 1938 Miyako-jima-Hokusei-oki Earthquake with $M=7.2$, the largest shallow earthquake recorded in the OT, occurred in this area, and a tsunami with a height of $1.5 \mathrm{~m}$ was observed at Miyako-jima. Despite the uncertainty of the epicentral location, high seismicity and several faults cutting the seafloor around Miyako Seamount suggest that the source region is positioned around this area.

There is another active seismic region to the north of Miyako Seamount interpreted as a remnant fragment of the continent on the basis of rock samples (e.g., Katsura et al. 1986). The crustal thickness below Miyako Seamount of over $15 \mathrm{~km}$ (Fig. 5) supports the continental/arc crust origin. An enlarged MCS profile for ECr6 across the seamount is shown in Fig. 19, revealing that several normal faults cutting the basement of Miyako Seamount and the fault throws in the northwest of the seamount are more significant than those in the southeast. The MCS profile along the Miyako Rift in ECr22 shows that normal faulting is more active in the region with high seismicity. However, the global CMT solutions were more frequently located in the south of the seamount, and more precise information regarding the hypocenter locations is necessary to determine the relationship with the seismic structure. 


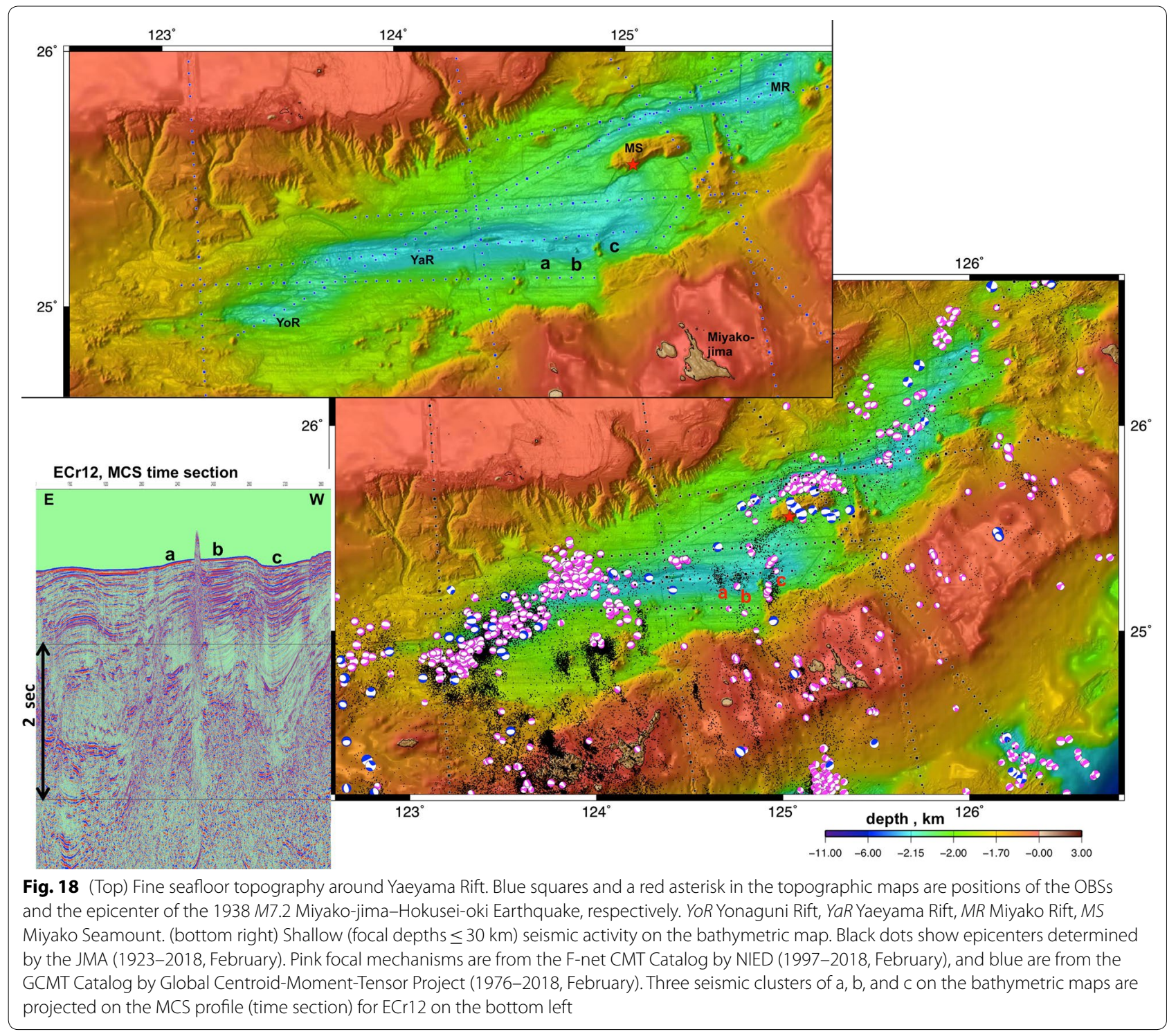

\section{Conclusions}

We acquired 17 seismic lines to study the fine seismic structure related to the active backarc rifting in the OT. Based on our results, the following main conclusions can be drawn.

1. Variation in the crustal thinning in the OT was inferred mainly from the Moho depth distribution based on Moho reflection (PmP) travel times. The across-trough seismic profiles show that the crust of the OT is thinner than below the ECS shelf and Ryukyu Island Arc. Along-trough variation in the Moho depths around the center of the trough decreases from over $25 \mathrm{~km}$ in the north to $\sim 13 \mathrm{~km}$ in the south, indicating a spatial difference in the degree of crustal thinning.

2. The position of the shallowest Moho along the across-trough lines in the northern and middle OT does not necessarily correspond to the center of the trough, defined as the deepest seafloor, but it corresponds to the northwestern margin of the OT, the transition area between the ECS shelf and the OT. The M7.1 Satsuma-hanto Seiho-oki Earthquake occurred at the transition area on November 14, 2015, and intense aftershock activity was observed along the transition. This seismic activity demonstrated that the area is undergoing rifting tectonics at present. 


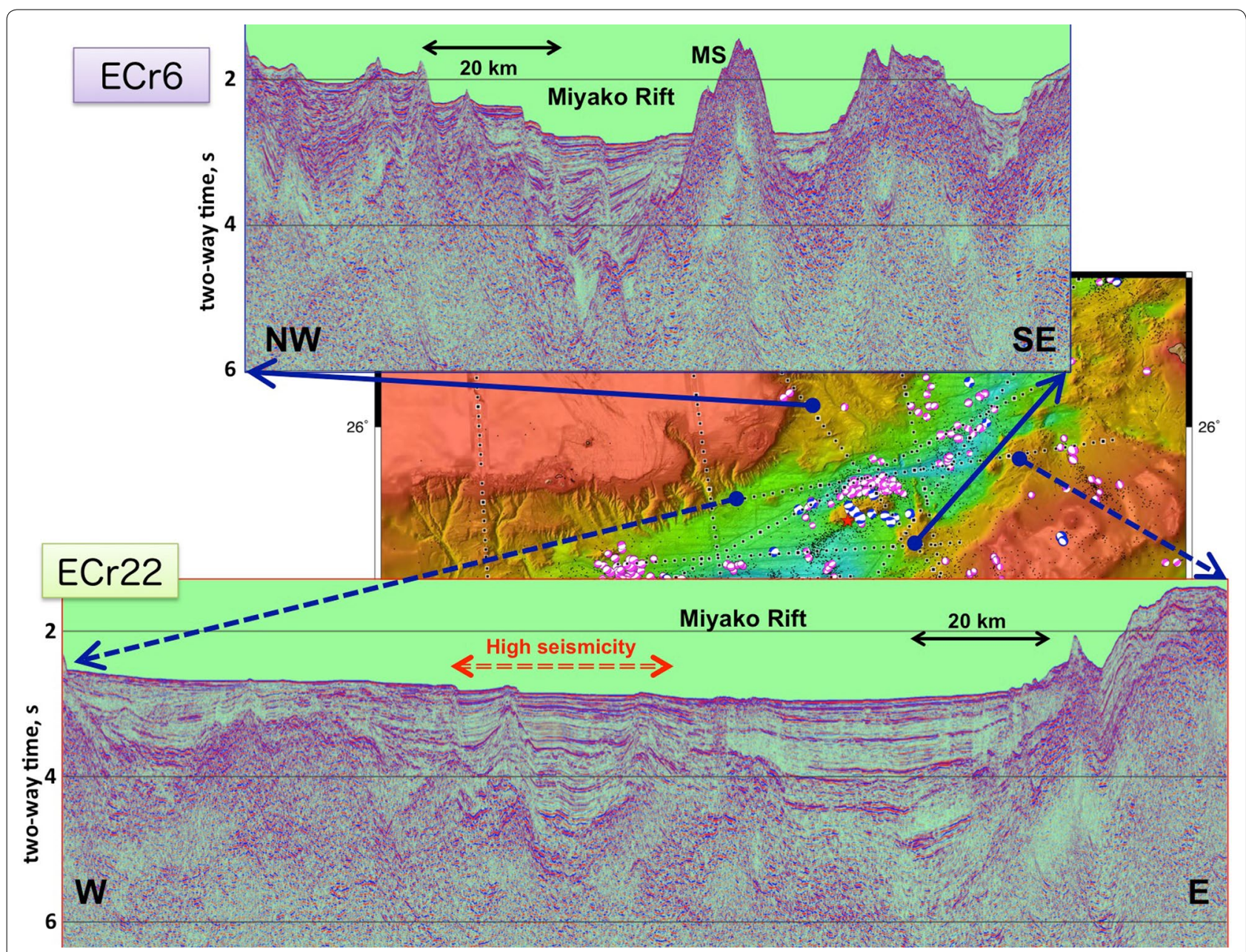

Fig. 19 MCS profiles (time sections) for ECr6 and ECr22 near the active seismic area around Miyako Seamount. Black dots show epicenters with focal depths $\leq 30$ km determined by the JMA (1923-2018, February) in the bathymetric map. Pink focal mechanisms are from the F-net CMT Catalog by NIED (1997-2018, February), and blue are from the GCMT Catalog (1976-2018, February). Black squares and a red asterisk in the topographic maps (center) are positions of the OBSs and the epicenter of the 1938 M7.2 Miyako-jima-Hokusei-oki Earthquake, respectively

3. In the southern OT, the thinnest crust of $\sim 7 \mathrm{~km}$ excluding top sediments was observed below the Yaeyama Rift, the deepest area at the center of the trough. Despite its thin thickness, the crust is continuous between the ECS shelf and Ryukyu Island Arc and consists of the upper, middle, and lower crusts of the continental/island arc.

4. The seismic structure across the rifts, which are the characteristic seafloor topography in the southern OT, is nearly symmetric; however, more intrusions are detected in the MCS records on the southeastern side of the trough. Several slightly larger intrusions occasionally correspond to ascending higher $V_{\mathrm{p}}$ materials in the top sedimentary layers. These features suggest the possible existence of the volcanic front in the southern OT.
5. Active seismic regions in the southern OT where the crustal thinning is mostly progressing correspond to the areas with significant deformation in seafloor topography and seismic structures.

\section{Additional file}

Additional file 1 Additional figures showing enlarged MCS profiles with interpretation and OBS record sections for forward modeling.

\section{Abbreviations}

OT: Okinawa Trough; NOT: northern Okinawa Trough; MOT: middle Okinawa Trough; SOT: southern Okinawa Trough; ECS: East China Sea; BMFZ: BotanMiyako fracture zone; CMT: centroid moment tensor; MCS: multichannel seismic; PHS: Philippine Sea; OBS: ocean bottom seismograph; TV: Tokara Valley; KG: Kerama Gap; MS: Miyako Saddle; IS: Ishigaki Saddle; MJ: Miyako-jima; IJ: Ishigaki-jima; OH: Oki-Hateruma Basin; LOFZ: Luzon-Okinawa fracture zone; 
DM: Daiichi-Miyako Knoll; MS: Miyako Seamount; YoR: Yonaguni Rift; YaR: Yaeyama Rift; MR: Miyako Rift; NIED: National Research Institute for Earth Science and Disaster Resilience; JMA: Japan Meteorological Agency; DELP: dynamics and evolution of the lithosphere project.

\section{Authors' contributions}

$\mathrm{AN}, \mathrm{KK}, \mathrm{MO}, \mathrm{HD}, \mathrm{YF}$, and $\mathrm{CO}$ contributed to the analysis and interpretation of the seismic data. AN summarized the results and drafted the manuscript. $\mathrm{MO}, \mathrm{HD}, \mathrm{YF}$, and $\mathrm{CO}$ participated in the onshore surveys. KK, MO, and YF calculated Bouguer gravity anomalies. All authors read and approved the final manuscript.

\section{Author details}

${ }^{1}$ Hydrographic and Oceanographic Department, Japan Coast Guard, 3-1-1 Kasumigaseki, Chiyoda-ku, Tokyo 100-8932, Japan. ${ }^{2}$ Present Address: National Research Institute for Earth Science and Disaster Resilience, 3-1 Tennodai, Tsukuba, Ibaraki 305-0006, Japan.

\section{Acknowledgements}

We gratefully acknowledge Prof. Emeritus J. Kasahara and Drs. E. Nishiyama, A. Kamimura, K. Murase, H. Ohnuma, and M. Tomura, dedicated technicians of Kawasaki Geological Engineering Co., Ltd. and GJl, Inc. for help with data processing and analyses. We thank Dr. Y. Iwabuchi for critically reading this manuscript. We also thank members of the Continental Shelf Surveys Office, Hydrographic and Oceanographic Department, JCG, for the management of the seismic surveys. The editorial assistance of K. Yoshizawa and the lots of suggestions of an anonymous reviewer and Dr. F. Klingelhoefer, which greatly improved the quality of our manuscript, are gratefully acknowledged. Most of the figures in this paper were produced using the GMT graphic package of Wessel and Smith (1998)

\section{Competing interests}

The authors declare that they have no competing interests.

\section{Availability of data and materials}

Those who would like to access the seismic data used in this study need to contact the Hydrographic and Oceanographic Department, Japan Coast Guard (http://www1.kaiho.mlit.go.jp/jhd-E.html), and obtain the permission.

\section{Consent for publication}

Not applicable.

Ethics approval and consent to participate

Not applicable.

\section{Funding}

This study received no specific grant from any funding agency.

\section{Publisher's Note}

Springer Nature remains neutral with regard to jurisdictional claims in published maps and institutional affiliations.

Received: 31 August 2018 Accepted: 5 February 2019

Published online: 20 February 2019

\section{References}

Arai R, Kodaira S, Kaiho Y, Takahashi T, Miura S, Kaneda Y (2017) Crustal structure of the southern Okinawa Trough: Symmetrical rifting, submarine volcano, and potential mantle accretion in the continental back-arc basin. J Geophys Res Solid Earth. https://doi.org/10.1002/2016jb013448

Arai R, Kodaira S, Takahashi T, Miura S, Kaneda Y (2018) Seismic evidence for arc segmentation, active magmatic intrusions and syn-rift fault system in the northern Ryukyu volcanic arc, Earth Planets Space 70:61. https://doi. org/10.1186/s40623-018-0830-8

Beaulieu SE (2015) InterRidge global database of active submarine hydrothermal vent fields: prepared for InterRidge, Version 3.3. World Wide Web electronic publication. Version 3.4. http://vents-data.interridge.org. Accessed 29 Oct 2018
Fujie G, Kasahara J, Sato T, Mochizuki K (2000) Traveltime and raypath computation: a new method in a heterogeneous medium. J Soc Explor Geophys Jpn 53:1-11

Furukawa M, Tokuyama H, Abe S, Nishizawa A, Kinoshita H (1991) Report on DELP 1988 cruises in the Okinawa Trough, 2, Seismic reflection studies in the southwestern part of the Okinawa Trough. Bull Earthquake Res Inst Univ Tokyo 66:17-36

Gungor A, Lee GH, Kim HJ, Han HC, Kang MH, Kim J, Sunwoo D (2012) Structural characteristics of the northern Okinawa Trough and adjacent areas from regional seismic reflection data: geologic and tectonic implications. Tectonophysics 522-523:198-207

Hirata N, Kinoshita H, Katao H, Baba H, Kaiho Y, Koresawa S, Ono Y, Hayashi K (1991) Report on DELP 1988 cruises in the Okinawa Trough Part3. Crustal structure of the southern Okinawa Trough. Bull Earthq Res Inst Univ Tokyo 66:37-70

Inoue T (2007) Tectonic history of the East China Sea, a research review. Chishitsu News 633:37-44 (in Japanese)

InterRidge Vents Database Ver.3.4, hydro-thermal vent data are downloadable from http://vents-data.interridge.org/ventfields?order =name_3\&sort=asc. Accessed 29 Nov 2018

Ishibashi J, Ikegami F, Tsuji T, Urabe T (2015) Hydrothermal activity in the Okinawa Trough back-arc basin: Geological Background and Hydrothermal Mineralization. In: Ishibashi J, Okino K, Sunamura M (eds) Subseafloor Biosphere Linked to Hydrothermal Systems. Springer, Tokyo. https://doi. org/10.1007/978-4-431-54865-2_27

Ishikawa M, Sato M, Furukawa M, Kimura M, Kato Y, Tsugaru R, Shimamura K (1991) Report on DELP 1988 cruises in the Okinawa Trough Part 6: petrology of volcanic rocks. Bull Earthquake Res Inst Univ Tokyo 66:151-177

Iwasaki T, Hirata N, Kanazawa T, Melles J, Suyehiro K, Urabe T, Moller L, Makris J, Shimamura H (1990) Crustal and upper mantle structure in the Ryukyu island arc deduced from deep seismic sounding. Geophys J Int 102:631-651

Katsura T, Oshima S, Ogino T, Ikeda K, Nagano M, Uchida M, Hayashida M, Koyama K, Kasuga S (1986) Geological and geophysical characteristics of the Southwestern Okinawa Trough and adjacent area. Rep Hydrogr Res 21:21-47

Kimura M (1990) Genesis and formation of the Okinawa Trough, Japan (in Japanese with English abstr.). Mem Geol Soc Jpn 34:77-88

Klingelhoefer F, Lee CS, Lin JY, Sibuet JC (2009) Structure of the southernmost Okinawa Trough from reflection and wide-angle seismic data. Tectonophysics 466:281-288

Klingelhoefer F, Berthet T, Lallemand S, Schnurle P, Lee CS, Liu CS, McIntosh K, Theunissen T (2012) P-wave velocity structure of the southern Ryukyu margin east of Taiwan: results from the ACTS wide-angle seismic experiment. Tectonophysics 578:50-62

Korenaga J, Holbrook WS, Kent GM, Kelemen PB, Detrick RS, Larsen HC, Hopper JR, Dahl-Jensen T (2000) Crustal structure of the southeast Greenland margin from joint refraction and reflection seismic tomography. J Geophys Res 105:21591-21614. https://doi.org/10.1029/2000JB900188

Kubota R, Nishiyama E, Murase K, Kasahara J (2009) Traveltime estimation of first arrivals and later phases using the modified graph method for a crustal structure analysis. Explor Geophys 40:105-113

Larsen SC, Schultz CA (1995) ELAS3D: 2D/3D elastic finite-difference wave propagation code. Lawrence Livermore National Laboratory technical Report No. UCRL-MA-121792, pp 19

Lee CS, Shor GG, Bibee LD, Lu RS, Hilde TWC (1980) Okinawa Trough: origin of a back-arc basin. Mar Geol 35:219-241

Letouzey J, Kimura M (1986) The Okinawa Trough: genesis of a back-arc basin developing along a continental margin. Tectonophysics 125:209-230

Li CF, Zhou Z, Ge H, Mao Y (2009) Rifting process of the Xihu Depression, East China Sea Basin. Tectonophysics 472:135-147

Lin JY, Sibuet JC, Hsu SK (2005) Distribution of the East China Sea continental shelf basins and depths of magnetic sources. Earth Planets Space 57:1063-1072

Ludwig WJ, Murauchi S, Den N, Buhl P, Hotta H, Ewing Jl, Asanuma T, Yoshii T, Sakajiri N (1973) Structure of East China Sea-West Philippine Sea margin, off southern Kyushu, Japan. J Geophys Res 78:2526-2536

Miki M (1995) Two-phase opening model for the Okinawa trough inferred from paleomagnetic study of the Ryukyu arc. J Geophys Res 100:8169-8184 
Minami H, Ohara Y (2017) The Gondou hydrothermal field in the Ryukyu Arc: a huge hydrothermal system on the flank of a caldera volcano Geochem. Geophys Geosyst 18:3489-3516. https://doi.org/10.1002/2017GC006868

Murauchi S, Den N, Asano S, Hotta H, Yoshii T, Asanuma T, Hagiwara K, Ichikawa K, Sato T, Ludwig WJ, Ewing Jl, Edgar NT, Houtz RE (1968) Crustal structure of the Philippine Sea. J Geophys Res 73:3143-3171

Nagumo S, Kinoshita H, Kasahara J, Ouchi T, Tokuyama H, Asanuma T, Koresawa S, Akiyoshi H (1986) Report on DELP 1984 cruises in the middle Okinawa Trough, Part Il: seismic structural studies. Bull Eartha Res Inst Univ Tokyo 61:167-202

Nakahigashi K, Shinohara M, Suzuki S, Hino R, Shiobara H, Takenaka H, Nishino M, Sato T, Yoneshima S, Kanazawa T (2004) Seismic structure of the crust and uppermost mantle in the incipient stage of back arc riftingnorthernmost Okinawa Trough. Geophys Res Lett 31:1-9. https://doi. org/10.1029/2003gl018928

Nakamura M, Umedu N (2009) Crustal thickness beneath the Ryukyu arc from travel-time inversion. Earth Planets Space 61:1191-1195

Nishizawa A, Kaneda K, Oikawa M (2011) Backarc basin oceanic crust and uppermost mantle seismic velocity structure of the Shikoku Basin, south of Japan. Earth Planets Space 63:151-155

Nishizawa A, Kaneda K, Katagiri Y, Oikawa M (2014) Wide-angle refraction experiments in the Daito Ridges region at the northwestern end of the Philippine Sea plate. Earth Planets Space 66:25. https://doi. org/10.1186/1880-5981-66-25

Nishizawa A, Kaneda K, Oikawa M, Horiuchi D, Fujioka Y, Okada C (2017) Variations in seismic velocity distribution along the Ryukyu (Nansei-Shoto) Trench subduction zone at the northwestern end of the Philippine Sea plate. Earth Planets Space 69:86

Oikawa M, Kaneda K (2007) Bouguer gravity anomaly in the Western Pacific. Tech Bull Hydrogr Oceanogr 25:96-99 (in Japanese with English abstract)

Okamura Y, Nishizawa A, Oikawa M, Horiuchi D (2017) Differential subsidence of the forearc wedge of the Ryukyu (Nansei-Shoto) Arc caused by subduction of ridges on the Philippine Sea Plate. Tectonophysics 717:399-412. https://doi.org/10.1016/j.tecto.2017.08.025
Oshida A, Tamaki K, Kimura M (1992) Origin of the magnetic anomalies in the Southern Okinawa Trough. J. Geomag. Geoelectr. 44:45-359

Oshida A, Kubota R, Nishiyama E, Ando J, Kasahara J, Nishizawa A, Kaneda K (2008) A new method for determining OBS positions for crustal structure studies, using airgun shots and precise bathymetric data. Explor Geophys 39:15-25

Oshima S, Takanashi M, Kato S, Uchida M, Okazaki I, Kasuga S, Kawashiri C, Kaneko Y, Ogawa M, Kawai K, Seta H, Kato Y (1988) Geological and geophysical survey in the Okinawa Trough and the adjoining seas of Nansei Syoto. Rep Hydrogr Res 24:19-43

Park JO, Tokuyama H, Suyehiro K, Taira A (1998) Seismic record of tectonic evolution and Backarc rifting in the southern Ryukyu island arc system. Tectonophysics 294:21-42

Sibuet JC, Hsu SK (1997) Geodynamics of the Taiwan arc-arc collision. Tectonophysics 274:221-251

Sibuet JC, Hsu SK, Shyu CT, Liu CS (1995) Structural and kinematic evolution of the Okinawa trough Backarc basin. In: Taylor B (ed) Backarc basins: tectonics and magmatism. Plenum Press, New York, pp 343-378

Sibuet JC, Deffontaines B, Hsu SK, Thareau N, Le Formal JP, Liu CS, ACT Party (1998) Okinawa Trough backarc basin: early tectonic and magmatic evolution. J Geophys Res 103:30245-30267

Sibuet JC, Hsu SK, Debayle E (2004) Geodynamic context of the Taiwan orogen. In: Clift P, Wang P, Kuhnt W, Hayes DE (eds) Continent-ocean Interactions within East Asian Marginal seas. American Geophysical Union Monograph, Washington, pp 127-158

Takahashi N, Kodaira S, Tatsumi Y, Kaneda Y, Suyehiro K (2008) Structure and growth of the Izu-Bonin-Mariana arc crust: 1. Seismic constraint on crust and mantle structure of the Mariana arc-back-arc system. J Geophys Res 113:B01104. https://doi.org/10.1029/2007jb005120

Wessel P, Smith WHF (1998) New, improved version of the generic mapping tools released. EOS Trans AGU 79:579

Yamanaka T et al (2015) The Tarama Knoll: geochemical and biological profiles of hydrothermal activity. In: Ishibashi J et al (eds) Subseafloor biosphere linked to hydrothermal systems. Springer, Japan, pp 497-504. https://doi. org/10.1007/978-4-431-54865-2_40

\section{Submit your manuscript to a SpringerOpen ${ }^{\odot}$ journal and benefit from:}

- Convenient online submission

- Rigorous peer review

- Open access: articles freely available online

- High visibility within the field

- Retaining the copyright to your article

Submit your next manuscript at $\boldsymbol{\nabla}$ springeropen.com 